\title{
LSE
}

\section{Symmetry and Convergence in Monetary Unions}

Nauro F. Campos and Corrado Macchiarelli

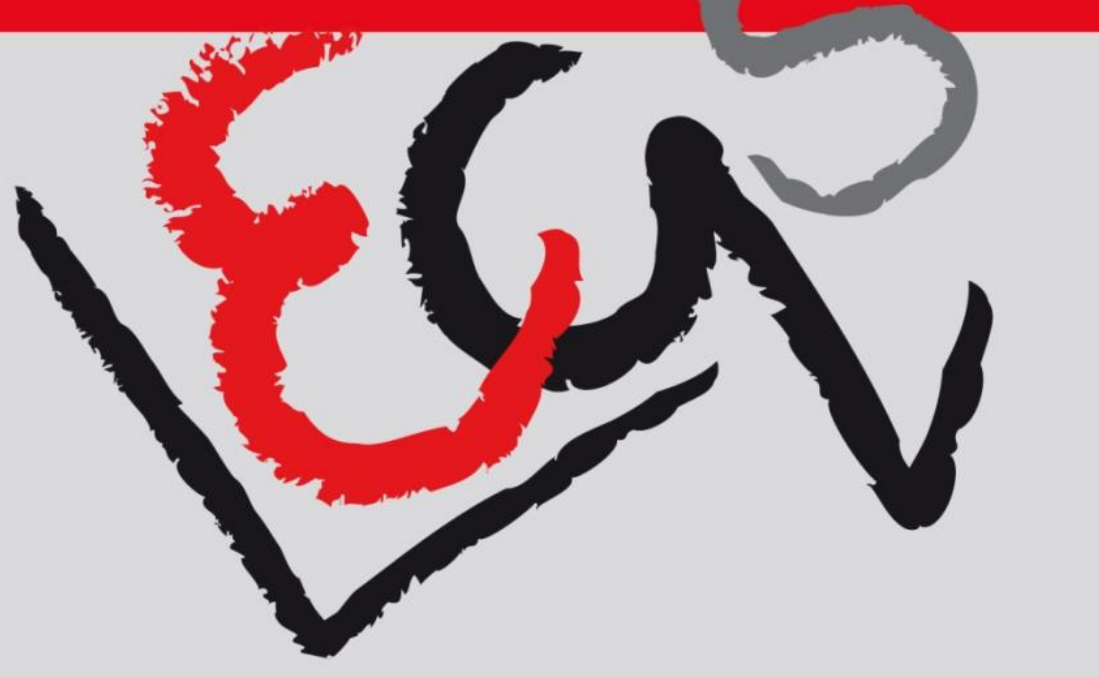




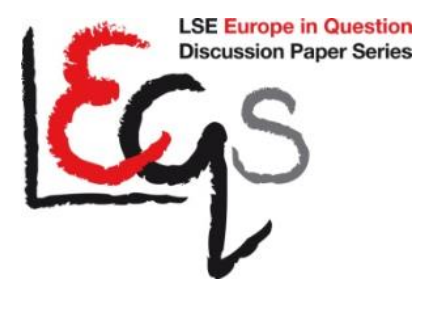

\section{Editorial Board}

Dr Bob Hancke

Dr Jonathan White

Dr Sonja Avlijas

Dr Auke Willems

Mr Hjalte Lokdam

All views expressed in this paper are those of the authors and do not necessarily represent the views of the editors or the LSE.

(c) Nauro F. Campos and Corrado Macchiarelli 


\title{
Symmetry and Convergence in Monetary Unions
}

\author{
Nauro F. Campos* and Corrado Macchiarelli**
}

\begin{abstract}
This paper has three main objectives, namely to (a) propose a new framework that can support placing countries along a core-periphery continuum (beyond the more common binary treatment as either core or periphery), (b) to construct a continuous dynamic theory-based measure (the first, to the best of our knowledge) illustrating the use of this framework for a set of European countries using yearly data from 1960 to 2015, and (c) provide a first preliminary assessment, based on endogenous Optimal Currency Area (OCA) theory, of the main potential explanatory factors of the dynamics of this measure over time and across countries. Our main finding is that this new measure allows us to identify sets of countries on the basis of not only its level but also in terms of its dynamic behaviour. Using the Phillips-Sul procedure, we show the emergence a newer set of core countries (composed by Austria, Belgium, Germany, France, Italy and Netherlands), a mixed set of countries (namely Denmark, Sweden, Greece, Spain and the UK), and a set of deep-rooted periphery countries (Finland, Ireland, Norway, Portugal, and Switzerland). There are valuable lessons from the dynamics of this measure. It increases for core countries (which confirms endogenous OCA predictions), remains worrisomely constant for a periphery, and varies substantially for the intermediate set of countries. Spain (Sweden and Greece) becomes consistently more (less) core over time, Denmark's remains constant and the UK moves in and out of the core over time. Our panel estimates on a specification suggested by endogenous OCA theory imply that euro membership and more flexible product market regulations (or trade openness) make countries more likely to be in the core.
\end{abstract}

Keywords: Symmetry; Convergence; Euro; EMU; European Union; CorePeriphery; SVAR

JEL codes: E3; F4

\footnotetext{
* Brunel University London and ETH-Zurich

Email: nauro.campos@brunel.ac.uk

** Brunel University London and London School of Economics

Email: corrado.macchiarelli@brunel.ac.uk
} 


\section{Table of Contents}

1. Introduction

2. Core and Periphery in Optimum Currency Areas .4

3. Implementation .9

4. The Dynamics of Core and Periphery 15

5. Evaluating NORD ("Number of rejections dynamics") 25

6. Conclusions. 36

References 38

Appendices 40

Acknowledgments

We would like to thank Tamim Bayoumi, Iain Begg, Paul De Grauwe, Barry Eichengreen, Balazs Egert, Jarko Fidrmuc, Maurizio Habib, Christopher Hartwell, Rana Sajedi, Andre Sapir, Karl Whelan, and seminar participants at Brunel University London, University of Orleans, London School of Economics, Polish National Bank, Czech National Bank, Organization for Economic Cooperation and Development, Bank of England, 48th Money Macro and Finance Research Meeting, CASE Warsaw 25th Anniversary Conference, International Conference on "Economic Challenges for the Future of Europe" (Paris), Jean Monnet Conference on "Economic Prospects for the EU" (Dusseldorf), and XX Meetings of Applied Economics Association (Valencia) for valuable comments on previous versions of this paper. The usual disclaimer applies. 


\section{Symmetry and Convergence in Monetary}

\section{Unions}

\section{Introduction}

The protracted economic crisis in the Eurozone has fuelled demands for a deeper understanding of the dynamics of core and periphery groups of countries in the European Union, in general, and in its Economic and Monetary Union (EMU), in particular. There is now widespread consensus on the shortcomings of the EMU with even the European Commission openly recognising them and proposing as solution the building up of a Genuine EMU (Begg 2015). Such extensive agreement on the need for solutions co-exists with deep disagreement on causes. One view is that design flaws deepened imbalances (De Grauwe 2016) while another is that policy mistakes hindered convergence (Sandbu 2015). One solution that has been proposed is a flexible euro (Stiglitz 2016): a two-tier model of a Northern and a Southern Euro where the latter is softer. One tautological way to explain this is that the Southern euro countries would not be part of the core.

This paper has three main objectives, namely to (a) propose a new framework that can support placing countries along a core-periphery continuum (beyond the much more common binary treatment as either core or periphery), (b) to construct a continuous dynamic theory-based measure (the first, to the best of our knowledge) illustrating the use of this framework for a set of European countries using yearly data from 1960 to 2015, and (c) provide a first preliminary assessment, based on endogenous Optimal Currency Area 
(hereafter OCA) theory, of the main potential explanatory factors of the dynamics of this measure over time and across countries.

The natural point of departure is the seminal paper by Bayoumi and Eichengreen (1993). This is one of the first papers to identify a core-periphery pattern in the run-up to the European Monetary Union (EMU). Motivated by OCA theory and using a modified Blanchard-Quah decomposition within the Aggregate Supply-Aggregate Demand (AS-AD) framework, they estimate the degree of demand and supply shocks synchronization for 1963-1989 data. Bayoumi and Eichengreen show that there is a core where shocks are highly correlated (Germany, France, Belgium, Netherlands and Denmark) and a periphery where this correlation is significantly lower (Greece, Ireland, Italy, Portugal, Spain and UK). They forewarn that if persistent, this core-periphery pattern would be detrimental to the EMU project.

We follow the large literature started by Bayoumi and Eichengreen (1993) in that our exercise is also couched in the canonical AS-AD model. The model implies that positive demand shocks raise prices in both the short- and longrun with no output effects in the long-run, while positive supply shocks lower prices and increase output permanently. De Haan et al. (2008) and Santos and Tenreyro (2010) review this vast literature: It tends not to impose output related restrictions for tractability reasons as this choice leaves their models exactly identified. The novelty of our approach is to explicitly model these output considerations as over-identifying restrictions. We impose this overidentifying restriction in a structural VAR framework so that the predicted effects of supply shocks on output are accounted for.

There are three main findings regarding symmetry, convergence and correlates of symmetry. Firstly, modelling supply considerations as over-identifying restrictions produces a new theory-based continuous measure. Our measure is 
the percentage of times this fuller, or more structural, AS-AD model is rejected. The more frequently this full set of restrictions is rejected, the more peripheral a country is said to be. The lower this frequency is, that is, the less often the full AS-AD model is rejected for a given country in a given year, the higher is the probability of a country being classified as core. This is implemented by bootstrapping the original VAR residuals and counting the number of rejections at each bootstrap replication: country-years for which the AS-AD model is rejected more (less) than half of the time are classified as periphery (core). For convenience, we call our index NORD (as it reflects the "number of rejections dynamics.")

Secondly, we study convergence using the Phillips and Sul (2007) framework. Here, we are able to identify a new set of core countries (Austria, Belgium, France, Germany, Italy and Netherlands), an intermediary set (Denmark, Greece, Spain, Sweden and the UK), and a periphery (Finland, Ireland, Norway, Portugal and Switzerland). Notice that NORD decreases for the core countries (broadly confirming the endogenous OCA predictions), remains high and constant for a deep-rooted periphery (worrisomely corroborating Bayoumi and Eichengreen's early warnings), and varies substantially for a mixed set of countries. As for the latter, Spain moves towards the core over time. Greece and, somewhat surprisingly, Sweden become "more peripheral" over time. Denmark is practically static while the UK seems to charge in and out of the core.

The third main finding refers to our attempt to uncover factors that can help explain the variation of this new measure across countries and over time. We believe these correlates indicate whether or not our measure is doing a good job at capturing core, periphery, and their dynamics; the latter being an issue that has received scant attention in previous research. Using a specification based on endogenous OCA theory, panel estimates suggest that euro 
membership and stricter product market regulations make countries more or less core, respectively. Further, we find that trade openness and, to a lesser extent, foreign direct investment, help to "import competition" and in so doing substitute for regulations: imports (but not so much exports) increase the probability of a country being classified as core. The findings are robust to numerous changes in specification, measurement, estimators (e.g., OLS or probit) and split samples (e.g., post-crisis period).

The paper is organised as follows. Section 2 sets up the conceptual framework. Section 3 discusses implementation and estimation issues. Section 4 introduces our new measure. Section 5 presents econometric results evaluating the robustness of this new measure. Section 6 concludes.

\section{Core and Periphery in Optimum Currency Areas}

In this section, we discuss why to understand the importance and urgency of core and periphery dynamics in the European Union, in general, and in the EMU, in particular, one should go beyond the standard business cycles synchronisation framework and towards a more encompassing notion. Based on optimal currency area (OCA) theory considerations, we discuss other approaches to identify core-periphery sets so as to properly contextualise our effort.

The main research question driving the OCA scholarship regards the costs and benefits of sharing a currency (Alesina and Barro 2002). The main cost is the loss of monetary policy autonomy. Benefits are mostly in terms of reducing 
transaction costs and exchange rate uncertainty, and of increasing price transparency, trade and competition. ${ }^{1}$

One way of framing the issue of optimum currency areas (OCA) is presented by De Grauwe and Mongelli (2005). They study interactions between symmetry, flexibility and openness. Particularly, they show that there exists a minimum combination of these that countries must reach for a monetary union to generate positive net benefits (see also Farhi and Werning 2015). De Grauwe and Mongelli (2005) place the Eurozone (EU) within (outside) of the OCA-line suggesting that those countries are (not yet) sufficiently integrated to generate efficiency gains that can compensate for the macroeconomic costs of the union. They also note the degree of openness and symmetry may change over time. Before the EMU, there was an intense debate about the extent to which a monetary union affects symmetry (Krugman 1993). De Grauwe and Mongelli's (2005) view is that in the EU specialisation will bring about less symmetry and thus countries move downwards along the OCA plane.

There are at least two noteworthy recent developments in OCA theory. The original OCA formulation stressed labour mobility, product diversification and trade openness as key criteria and explored the possible endogeneity of currency unions (Frankel and Rose 1998). Recent work called attention to the additional role of credibility shocks. If there are varying degrees of policy commitment (furthering time inconsistency problems), countries with dissimilar credibility shocks should find it convenient to join a currency union (Chari et al. 2015).

1 The literature is surveyed in De Haan et al. (2008), Silva and Tenreyro (2010) and Glick and Rose (2016). 
A second recent and important strand highlights that, although OCA criteria are often thought of as independent, they should instead be considered jointly, e.g., by focusing on the interactions between openness and mobility (Farhi and Werning 2015).

The optimality of a currency area is a function of the relative power (and of the relative "distance") between its members. If these differentials are large, it is common to speak of a core and a periphery. It is expected that core countries would be those more closely meeting the OCA criteria. Given its importance for OCA, it is not surprising there have been various attempts to classify countries into core and periphery sets. A basic way of distinguishing these methods is whether or not core-periphery status is imposed a priori.

A statistical technique often used here is cluster analysis. This method helps to determine the overall number and the composition of different groupings (or clusters) given that the elements (countries or regions) which are assigned to a given cluster are more similar to each other than to those in other clusters according to pre-defined criteria. Cluster analysis is a broad statistical methodology that involves various ways of estimating these groups and the distance among them. These can be thought of as different algorithms differing in their criteria and efficiency in determining the composition of each cluster.

Artis and Zhang (2001) investigate actual and prospective membership of the EMU by applying clustering techniques to a set of variables suggested by the theory of Optimal Currency Areas. The OCA criteria they employ are the extent of synchronisation in business cycles (symmetry in output shocks), volatility in the real exchange rate, synchronisation in the real interest rate cycle, openness to trade, inflation convergence, and labour market flexibility. Their analysis reveals that the member countries may be divided into three groups: those belonging to the core (Germany, France, Austria, Belgium and the 
Netherlands), those part of a Northern periphery (Denmark, Ireland, the UK, Switzerland, Sweden, Norway and Finland) and those belonging to a Southern periphery (Spain, Italy, Portugal and Greece). Their method delivers a rather intuitive classification of countries and, more usefully, allows researchers to see how these classifications change for each of the OCA criteria and multiple combinations of them.

There are other, more theory-based, approaches. Bayoumi and Eichengreen (1993) is a seminal piece in this regard. They put forward an approach stressing business cycle synchronisation embedded in a standard Aggregate Demand and Aggregate Supply framework. Using 1960 to 1989 data, they classify countries into core and periphery groups and famously warn that the gap between these groups puts in risk the very planning of the Single Currency. We discuss these results below in greater detail, but it is important to bring to the fore a related paper by these authors that produces an objective index to classify countries into core and non-core.

Bayoumi and Eichengreen (1997) construct an "optimum-currency-area index for European countries." The crucial element of their approach is to identify the determinants of nominal exchange rate variability which they argue reflect OCA characteristics and support predictions of which countries pertain to each set. This is justified conceptually and empirically. Conceptually, they argue that OCA focuses on criteria that ultimately make exchange rates more stable and monetary unification less costly. In their model, bilateral exchange rate variability is a function of GDP, trade, economic structure dissimilarity, and a measure of output synchronisation. Using 1973 to 1992 data, they find these to carry the expected signs and that they are statistically significant, so they use them to forecast variability in 1987, 1991 and 1995. 
Their econometric analysis allows them to identify three groups: in the first "rapidly converging" group are Germany, Austria, Belgium, the Netherlands, Ireland and Switzerland. The second group is one that has experienced little convergence and contains United Kingdom, Denmark, Finland, Norway and France. The third group is a set of countries that are "gradually converging" to the EMU and includes Sweden, Italy, Greece, Portugal and Spain. The two most consequential results from this analysis, with the benefit of hindsight, are that (1) France is positioned in the set that diverges from the Maastricht criteria but (2) that overall "economic integration has thus increased countries' readiness for monetary integration" (Bayoumi and Eichengreen 1997, p 769).

A different estimation framework to analyse the issue of asymmetries in the EMU is Basse (2014) which uses cointegration and structural breaks to try to identify EMU core member countries. The OCA dimension he is most interested in is changes in sovereign credit risk (bond markets) and the sample includes only selected EMU members (Germany, France, Belgium, Austria, Finland, and the Netherlands.) The main finding raises questions about the suitability of France as a core country.

One final noteworthy approach in terms of providing useful insights to understanding core and periphery in the EMU involves studies in which membership is assigned in advance, a priori. Arestis and Phelps (2016) perform an "endogeneity analysis" of output synchronization (differentiating output amplitude from concordance) using panel data (covering 1994 to 2013), for all members as well as for different country groups, including core, periphery, central and eastern European countries, northern European countries and the euro-candidate countries. The quantification of trade-related and direct spillover channels associated with monetary integration gives insights into the relative importance of direct and indirect (through trade) synchronisation gains arising from EMU membership. For all members, membership and trade 
appear to increase both amplitude and coincidence of their business cycles. The individual group analysis shows that core and northern countries have experienced much larger trade spillovers in terms of synchronisation than peripheral and Central and Eastern European countries. They suggest future research on the direct euro membership effects by trying to unpack the role of institutions and changes in the transmission mechanism since the introduction of the single currency.

\section{Implementation}

The methodology introduced by Bayoumi and Eichengreen (1993) is an extension of the Blanchard and Quah (1989) procedure for decomposing permanent (supply) and temporary (demand) shocks. Consider a system where the true model is represented by an infinite moving average of a (vector) of variables, $X_{t}$, and shocks, $\epsilon_{t}$. Using the lag operator L, a bi-variate VAR featuring real GDP and its deflator can be written as an infinite moving average representation of demand and supply disturbances:

$$
X_{t}=A_{0} \epsilon_{t}+A_{1} \epsilon_{t-1}+A_{2} \epsilon_{t-2}+A_{3} \epsilon_{t-3}+\cdots=\sum_{i=0}^{\infty} L^{i} A_{i} \epsilon_{t}
$$

where $X_{t}=\left[\Delta y_{t}, \Delta p_{t}\right]$ and the matrices $A$ represent the impulse response functions of the shocks to the elements of $X$. It follows that

$$
\left[\begin{array}{l}
\Delta y_{t} \\
\Delta p_{t}
\end{array}\right]=\sum_{i=0}^{\infty} L^{i}\left[\begin{array}{ll}
a_{11 i} & a_{12 i} \\
a_{21 i} & a_{22 i}
\end{array}\right]\left[\begin{array}{c}
\epsilon_{d t} \\
\epsilon_{s t}
\end{array}\right]
$$

where $y_{t}$ and $p_{t}$ represent the logarithm of the adjusted output and prices and $\epsilon_{t}$ are i.i.d.disturbances, which identify supply and demand shocks (Ramey 2016). For the $i$-th country, $a_{11 i}$ represents element $a_{11}$, in matrix $A_{i}$ and so on. 
This framework implies that supply shocks have permanent effects on output, while demand shocks have temporary effects. Both have permanent (opposite) effects on prices. The cumulative effect of demand shocks on the change in output must be zero:

$$
\sum_{i=0}^{\infty} a_{11 i}=0
$$

so it can be estimated using a VAR. Each element can be regressed on lagged values of all the elements of $X$. Using B to represent these estimated coefficients:

$$
\begin{aligned}
& X_{t}=B_{1} X_{t-1}+B_{2} X_{t-2}+\cdots+B_{n} X_{t-n}+e_{t} \\
& =(I-B(L))^{-1} e_{t} \\
& =\left(I+B(L)+B(L)^{2}+\cdots\right) e_{t} \\
& =e_{t}+D_{1} e_{t-1}+D_{2} e_{t-2}+D_{3} e_{t-3}
\end{aligned}
$$

where $e_{t}$ represents the residuals from the VAR equations. In order to convert (4) into the model in (2) under (3), the residuals from the VAR, $e_{t}$, are transformed into demand and supply shocks using the standard relation between the VAR's residuals $\left(e_{t}\right)$ and demand and supply shocks, i.e. $e_{t}=C \epsilon_{t}$. For each country, exact identification of the $\mathrm{C}$ matrix requires four restrictions. Two are normalizations, which define the variance of the shocks $\epsilon_{d t}$ and $\epsilon_{s t}$. The third restriction is from assuming that demand and supply shocks are orthogonal to each other. The fourth that demand shocks have only temporary effects on output (equation 3).

Figure 1 reproduces the seminal results from Bayoumi and Eichengreen (1993.) Using pre-EMU data to estimate the degree of business cycles synchronization, Bayoumi and Eichengreen convincingly argue that there is a core (Germany, France, Belgium, Netherlands and Denmark) where supply shocks are highly correlated and a periphery (Greece, Ireland, Italy, Portugal, Spain, and the UK) 
where synchronisation is lower. Importantly, these two groups are clearly visible "to the naked eye," especially from the point of view of supply shocks.

Figure 1.

Pre-EMU core-periphery pattern (1960-1987)

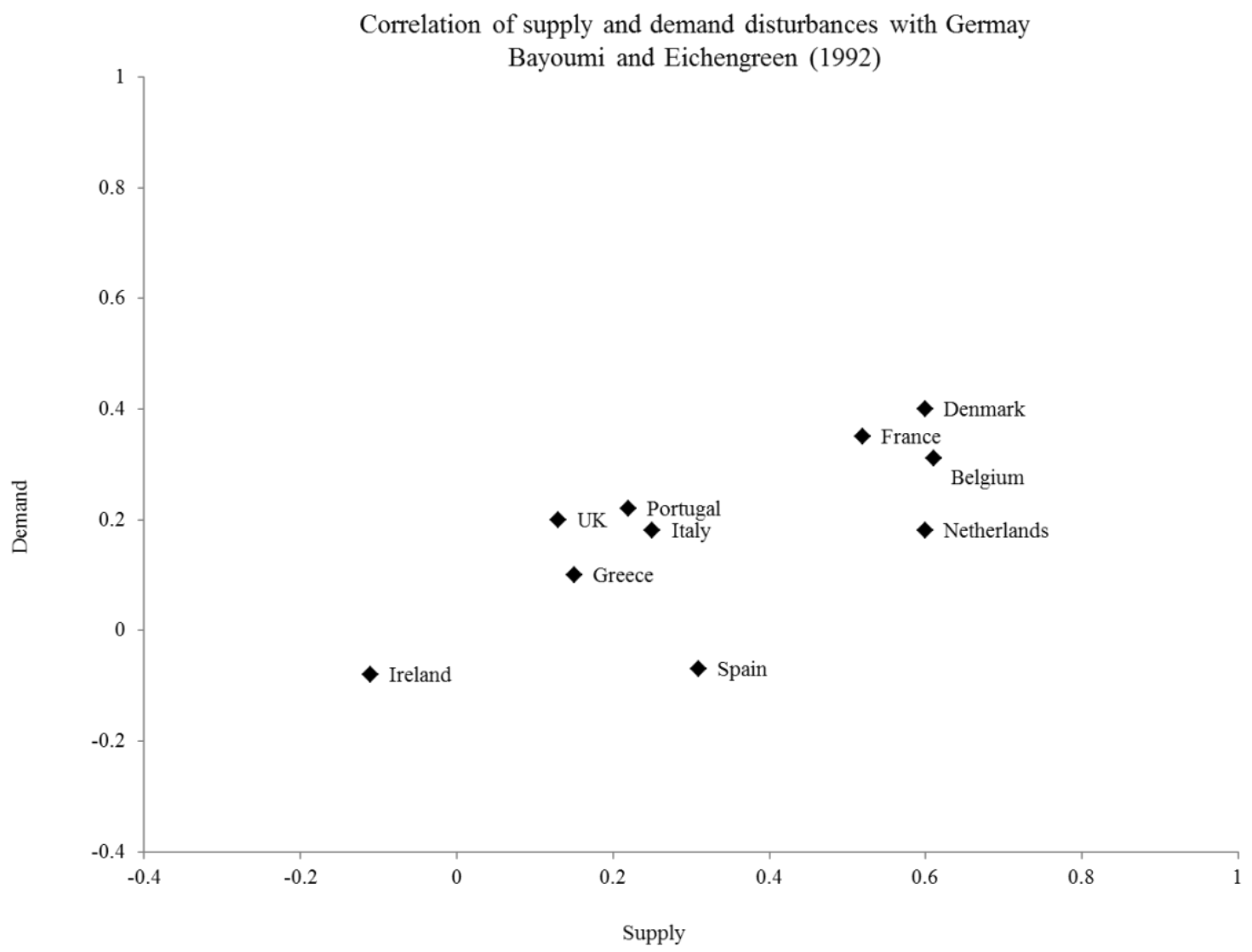

The standard AD-AS model implies that demand shocks raise prices in both the short and long run, while supply shocks lower prices and increase demand permanently. In order to fully reflect the structure of the underlying theoretical model, we impose an additional over-identifying restriction in the VAR that supply shocks have permanent effects on output. ${ }^{2}$

\footnotetext{
${ }^{2}$ In addition to trying to implement the AS-AD model more fully, another important reason we adopt the proposed over-identifying restriction is that inflation differentials are often considered a 'normal feature of currency unions' (see e.g., ECB 2017), hence we impose no restrictions on the reaction of inflation to demand and supply shocks, respectively.
} 
We pay particular attention to modelling the effect of permanent (supply) shocks on output, on top of the usual demand-side one. Since the proposed over-identifying restriction is sufficient to generate structural disturbances in line with AD-AS dynamics, any additional long-run restriction may be redundant in this setting.

Theoretically, testing for the "symmetry" of shocks also reflects the idea that the distinction between permanent and temporary shocks matters when it comes to adjustment within a currency union. According to De Grauwe (2016), when shocks are permanent, the slope of the usual existing trade-off between flexibility and symmetry is likely to depend on the nature of the shocks. Particularly, when permanent shocks dominate this tradeoff is likely to be steeper. Conversely, when temporary shocks dominate, the tradeoff will be flatter. We extend this idea further and suggest that it is not only the nature of the shock that matters but also the direction and extent by which shocks are pushing an economy "out of sync."

We test for symmetry of permanent shocks in our model by imposing $\sum_{i=0}^{\infty} a_{12 i}=\gamma$, where $\gamma>0$. This assumption implies that demand across each country respond qualitatively (sign) and quantitatively (size) in the same way to supply shocks. In terms of the structural VAR:

$$
\sum_{i=1}^{\infty}\left[\begin{array}{ll}
d_{11 i} & d_{12 i} \\
d_{21 i} & d_{22 i}
\end{array}\right]\left[\begin{array}{ll}
c_{11} & c_{12} \\
c_{21} & c_{22}
\end{array}\right]=\left[\begin{array}{ll}
0 & \gamma \\
. & .
\end{array}\right]
$$

In order to construct a test for the over-identifying restriction described above, we estimate a SVAR model that is fully consistent with Bayoumi and Eichengreen (1993). Differently from the literature that follows Bayoumi and Eichengreen, we bootstrap the original VAR residuals in a i.i.d. fashion and 
generate $\mathrm{K}=10.000$ data sets. ${ }^{3}$ For each of the $\mathrm{k}$-th samples, we proceed with a structural analysis and test for the over-identifying restriction based on a LRtest. We record the number of rejections of the over-identifying restriction test at each bootstrap replication and calculate the number of rejections (NORD):

$$
\operatorname{NORD}_{i}=100 \times \frac{\sum_{k=1}^{K}\left\{N O R D=1 \mid-2\left(L_{r}-L_{u}\right)>\chi_{\left.q-\left(\frac{n^{2}-n}{2}\right)\right\}_{i, k}}\right.}{K}
$$

where $L_{u}$ and $L_{r}$ are the maximized values of the (Gaussian) log likelihood function of the unrestricted and restricted regressions, respectively. Under $H_{0}$, the LR statistic has an asymptotic distribution with degrees of freedom equal to the number of long-run restrictions $(q)$ minus $\left(n^{2}-n\right) / 2$, where $n$ is the VAR-dimension (in this case $n=2$ ). We calculate $N O R D_{i}$ for different values of $\gamma$. Notice that we do not restrict $\gamma$ to a fixed value a priori. Instead, we vary $\gamma$ in the interval $[0.1,2]$ We then chose the value of $\gamma$ which minimizes the total number of rejections in the sample (Table 1A.) Demand and supply shocks are then retrieved by bootstrap, in particular recalculating the VAR parameters (K $=10.000$ ), identifying the SVAR and considering median values of structural disturbances under $\gamma=1$.

As noted above, the seminal Bayoumi and Eichengreen (1993) paper uses data from 1960 to 1988, that is, prior to the EMU and the euro. In order to assess the effect of the EMU, Campos and Macchiarelli (2016) use the same estimation methodology (SVAR with two lags for all countries, no constant, and yearly data with respect to Germany), sample of 12 countries, and time window (25

\footnotetext{
${ }^{3}$ One concern is the possible effects from any regime changes between 1960 and 2015. Using a dummy saturation approach, first proposed by Hendry et al. (2008), we attempt to detect model selection problems and correct the original series for possible regime changes. In the light of the above, we identify three regimes for both GDP and inflation, broadly consistent across countries: 1960:I-1969:I; 1984:I-1992:I; and 2008:I-2015:I.
} 
years), but with the (median bootstrapped) residuals and over-identifying restriction imposed for the sample 1989-2015. Figure 2 shows their results.

\section{Figure 2.}

Post-EMU core-periphery pattern (1990-2015)

Correlation of supply and demand disturbances (Bootstrapped residuals median values)

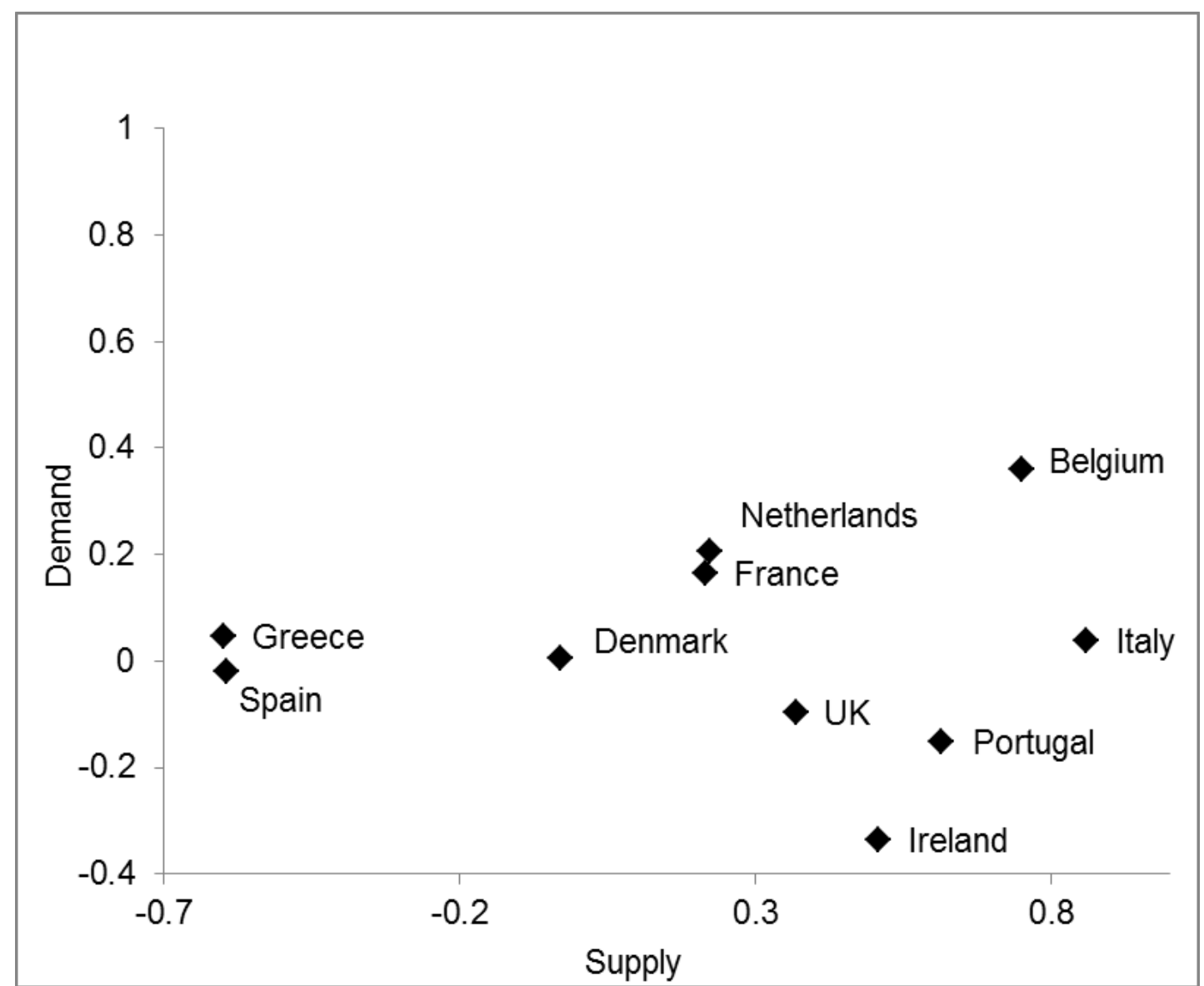

Note: This figure reports median bootstrapped residuals based on 10.000 VAR replications. Structural residuals are retrieved from a SVAR where the over-identifying restriction above is imposed for all countries, with the exception of Ireland, Spain, Greece and Portugal. The sample for this SVAR is 1989-2015, with two lags for all countries and no constant as in Bayoumi and Eichengreen (1993). The demand and supply disturbances correlation coefficients are reported in Appendix Table 4A.

Source: Campos and Macchiarelli (2016)

A comparison of the results in Figure 1 with those in Figure 2 help shed light on whether the EMU strengthened or weakened the core-periphery pattern. This comparison suggests that the introduction of the euro weakened or loosened the original divide. It is also clear, however, that this now cannot be grasped simply through visual inspection. In other words, the identification of core and periphery groups can not anymore be carried out by "the naked eye." 
A quantitative measure appears to have become necessary. Using $N O R D$, there is now a larger number of countries in the core, a smaller number in the periphery, and the distance between the two groups is shorter. The new smaller periphery is comprised solely of Spain, Portugal, Ireland and Greece, with the UK and Italy having joined the core since the late 1980s.

\section{The Dynamics of Core and Periphery}

Three major drawbacks from the existing empirical measures of symmetry in currency unions are that (a) they tend not to be continuous (a country is classified either as core or as periphery), (b) they are often imposed a priori and (c) they tend to be time-invariant. One may add that most of these measures are not theory-based. The approach we develop above generates a new type of measure that relaxes these main constraints.

One way of thinking about it is in terms of assessing parameter constancy. Let $\mathrm{T}$ be larger than before (55 years, i.e. 1960-2015) and $\tau$ denote the width of a sub-sample (25 years) or window and define the rolling sample metrics:

$$
N O R D_{\mathrm{t}_{\mathrm{i}}}(\tau)=\frac{1}{\tau-1} \sum_{j=0}^{\tau-1} N O R D_{(t-j) i}(\tau)
$$

The windows are rolled through the sample one observation at a time, so that the procedure returns $T-\tau+1$ rolling estimates of each parameter. Using a fixed 25-year window, we obtain a value representing the end-of-period number of rejections for each year, out of the number of the bootstrap replications. This number thus represents the count of the number of times the over-identifying restriction in the AS-AD framework is rejected for each country for the selected time period. The window is then rolled one observation at a time and new estimates are obtained for the whole time-series. 
These results are presented in Figures 3 to 7 which show $N O R D_{\mathrm{t}_{\mathrm{i}}}$ for various groups of countries, yearly from 1987 to 2015 . Figure 3 shows all 16 countries in our sample. We generate our measure for all European countries for which the required data series are available between 1960 and 2015. Figure 3 is shown simply to illustrate as clearly as possible that in our case it is practically impossible to differentiate groups of countries "at the naked eye." Therefore, a more systematic and transparent procedure is needed.

\section{Figure 3.}

NORD for 16 countries, 1990-2015 (Core-periphery dynamics)

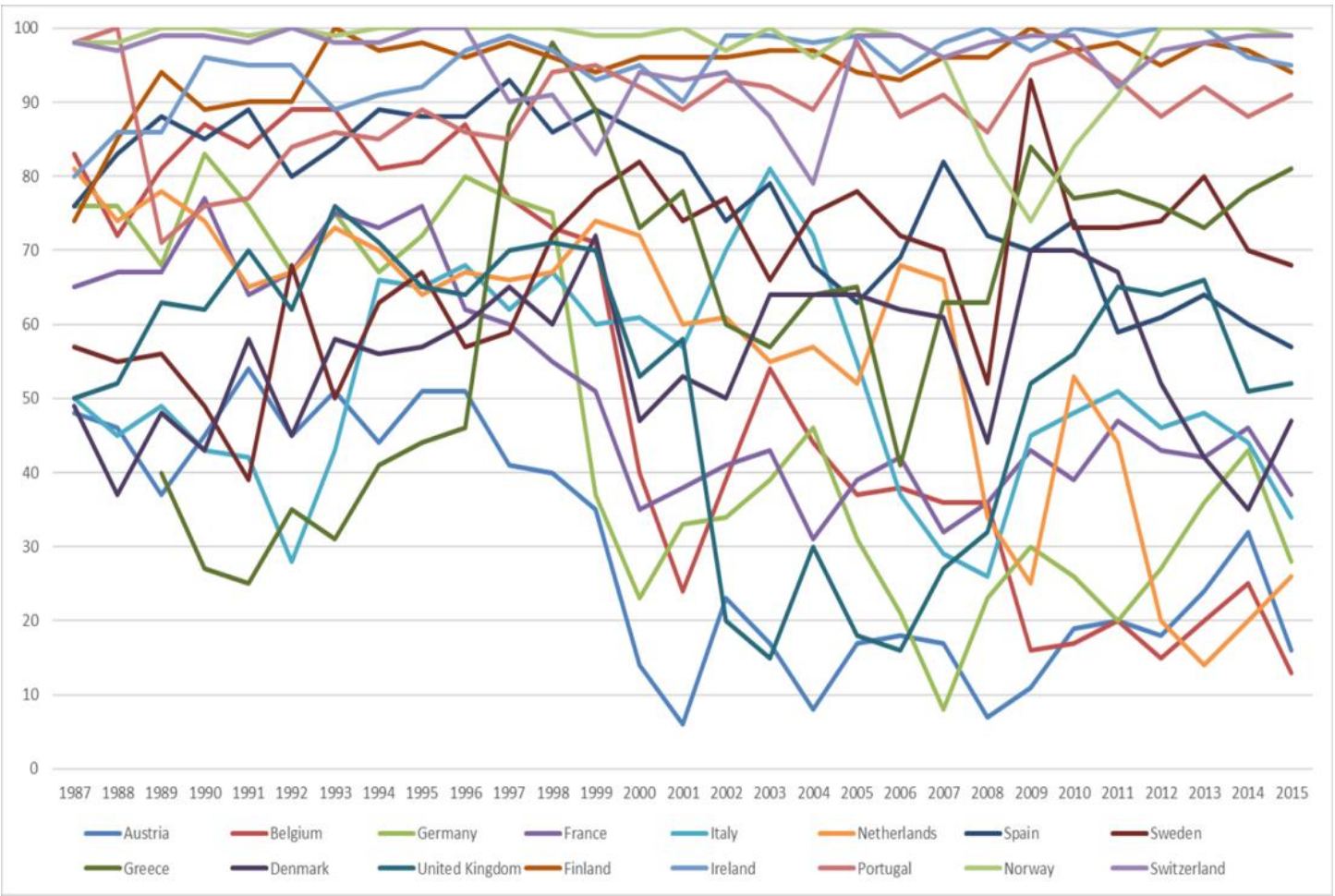

Another criticism to the approach we propose above, particularly in deriving our indicator from bivariate VARs that take into consideration GDP and its deflator only, is that the number of rejections may be capturing common (or, in this case, euro) area factors. In other words, the number of rejections of the symmetry hypothesis may be lower in those countries where common factors are stronger. To try to address this concern in full, we use the panel data model first proposed by Phillips and Sul (2007). For each time-series of our indicator, 
the model assumes both common and individual specific components and is formulated as a nonlinear time-varying factor model, allowing for a wide range of possible time paths and individual heterogeneity. This decomposition provides flexibility in idiosyncratic behaviour over time and across crosssections while retaining some commonality across the panel by means of an unknown common component which we identify as a latent 'euro area factor'. In this case, commonality means that when the heterogeneous time-varying idiosyncratic components converge over time to a constant, a form of panel convergence holds, which is analogous to the concept of conditional sigma convergence. The procedure not only does not impose any particular assumption concerning trend stationarity, thereby being robust to the stationarity property of the time series process, but also has the advantage of singling out a common factor, isolating it from idiosyncratic factors.

The measure we derived above, NORD, is a bounded variable $[0,100]$ and cannot be described by a random walk. However, both from an empirical and theoretical point of view, if its adjustment is slow, NORD may behave approximately as a random walk over the sample period. That is, within the chosen sample, the process does not show any tendency to be mean-reverting. This is evident by looking at the pattern of the dynamics of our indicator (particularly for what we have identified as peripheral countries.) When a process is close to having a unit root, the misspecified model introduced by assuming a unit root can be a good approximation to the true data-generating process. In fact, the misspecification introduced by assuming stationarity when in reality there is a unit root leads to more serious errors of inference. The issue may be important in our case if one assumes that structural euro area factors are increasing or reducing the degree of symmetry amongst countries, such that a path dependency of symmetry exists. 
Formally, the approach Phillips and Sul $(2007,2009)$ propose allows to isolate a common factor from the estimated dynamic NOR (NORD), distinguishing it from country-specific factors. The common factor may represent the aggregated common behaviour, but it could also be any common variable of influence on individual behaviour.

The starting point of the model is decomposing the panel data of our variable of interest, $N O R D_{i t}$, as:

$$
N O R D_{i t}=g_{i t}+a i t
$$

where $g_{i t}$ represents systematic components (such as permanent common component), and $a_{i t}$ reflects country-specific transitory components. In order to separate common from idiosyncratic components, Eq. (1.8) is further transformed as:

$$
N O R D_{i t}=\left(\frac{g_{i t}+a i t}{e a_{t}}\right) e a_{t}=\delta_{i t} u_{t}
$$

where $\delta_{i t}$ is a time varying idiosyncratic element and $e a_{t}$ is a single common ('euro area') component. Equation 9 is a dynamic factor model where $u_{t}$ captures some deterministic or stochastically trending behaviour and $\delta_{i t}$ is the time varying factor-loading.

In the general case, it is impossible to estimate the model directly without imposing some structure on $\delta_{i t}$ and $a_{t}$. Phillips and Sul (2007) propose removing the common factor by scaling so as to obtain the relative loading coefficient:

$$
h_{i t}=\frac{X_{i t}}{\frac{1}{N} \sum_{i=1}^{N} X_{i t}}=\frac{\delta_{i t}}{\frac{1}{N} \sum_{i=1}^{N} \delta_{i t}}
$$

which they called the "relative transition parameter," measuring the loading coefficient relative to the panel average at time $t$. By definition, $h_{i t}$ traces out a 
transition path of individual $i$ in relation to the panel average (Phillips and Sul 2007).

We use the Philipps and Sul econometric toolbox to evaluate the convergence properties of the estimated time-varying idiosyncratic components. Their suggested procedure for clustering panel data into clubs with similar convergence characteristics is as follows:

$$
\lim _{t \rightarrow \infty} \frac{X_{i t}}{X_{j t}}=1 \text { for } \forall i, j
$$

Phillips and Sul (2007) define this condition as "relative convergence." This condition is equivalent to convergence of the time varying factor-loading coefficient:

$$
\lim _{t \rightarrow \infty} \delta_{i t}=\delta \text { for } \forall i
$$

Showing that the cross sectional mean of $h_{i t}$ is unity and the cross sectional variance of $h_{i t}$ satisfies the condition $H_{i t}=\frac{1}{N} \sum_{i=1}^{N}\left(h_{i t}-1\right)^{2} \rightarrow$ 0 if $\lim _{t \rightarrow \infty} \delta_{i t}=\delta$ for $\forall i$, Phillips and Sul (2007) develop a regression test of the null hypothesis of convergence. Specifically, the hypothesis is implemented by means of the following ' $\log t^{\prime}$ regression model:

$$
\begin{aligned}
& \log \left(\frac{H 1}{H_{t}}\right)-2 \log (\log (t))=a+b \log (t)+\epsilon_{t} \\
& \text { for } t=[r T],[r T]+1, \ldots, T \text { with } r>0
\end{aligned}
$$

where $r$ is a selection of the initial sample fraction. Phillips and Sul's Monte Carlo simulations indicate that $r \in[0.2,0.3]$ achieves a satisfactory performance. In line with their results, we set $r=0.3$ because of the short time series in our panel $(T=29)$.

When we run the $\log t$ regression for the convergence test under the null hypothesis of convergence for the whole panel, the value of the $t$ statistic is - 
5.5874 which is less than -1.65 , hence the null hypothesis of overall convergence is rejected at the $5 \%$ level. However, the rejection of the hypothesis does not exclude the possibility of the existence of convergence clubs. When testing for convergence among sub-groups, the clustering of convergence sub-groups suggests the following partition:

Club 1: Ireland, Norway, Switzerland

Club 2: Finland, Greece, Portugal, Sweden

Club 3: Denmark, Spain, UK

Club 4: France, Italy

Club 5: Austria, Belgium, Germany, the Netherlands

The results suggest all the clubs fulfil the convergence hypothesis jointly (Appendix 9). However, the interpretation of the t-statistics requires care: while the Phillips and Sul's routine may have a natural interpretation for the extent of incremental economic growth and convergence across countries, the intuition regarding the convergence pattern in the degree of symmetry reflected by NORD may be less straightforward. In fact, in our setting countries showing the strongest degree of divergence from the core are often the ones for which the NORD has the strongest root.

To further investigate this issue, we perform the tests for possible club mergers Phillips and Sul (2007) suggest. These show statistical support to the possibility that the original Clubs 1 and 2 and 3 and 4 can be merged to form larger convergence clubs. This implies that three main clubs of countries may have emerged since the euro introduction, namely an extended periphery composed by Finland, Ireland, Norway, Portugal, Switzerland, Sweden, Greece, an intermediate group formed by Denmark, Spain, UK, France, and Italy, and a harder core where one would find Austria, Belgium, Germany, the 
Netherlands. It is noteworthy that these results are consistent with previous analyses (e.g., Campos and Macchiarelli 2016).

Figure 4 shows a first group that have in common a sustained decline in the probability of being classified as periphery (i.e., NORD). We call it the core group. Using the convenient 50\% mark for these classification purposes, one can see that the three first countries to enter the core are Germany, France and Austria, all by 1999. This is of course the year in which the euro was introduced. Belgium joins the core in 2000, while Italy and the Netherlands join before 2007. If one equates core membership with a strong indication of being part of an optimum currency area (OCA), these results are unique in that they show a somewhat gradual formation over time of an OCA. Moreover, if one accepts this interpretation, the results in Figure 3 provide evidence in favour of endogenous OCA theory (Frankel and Rose 1998) as countries only enter or join the core after the currency union is in place.

Figure 4.

NORD for core countries, 1990-2015 (Core-periphery dynamics)

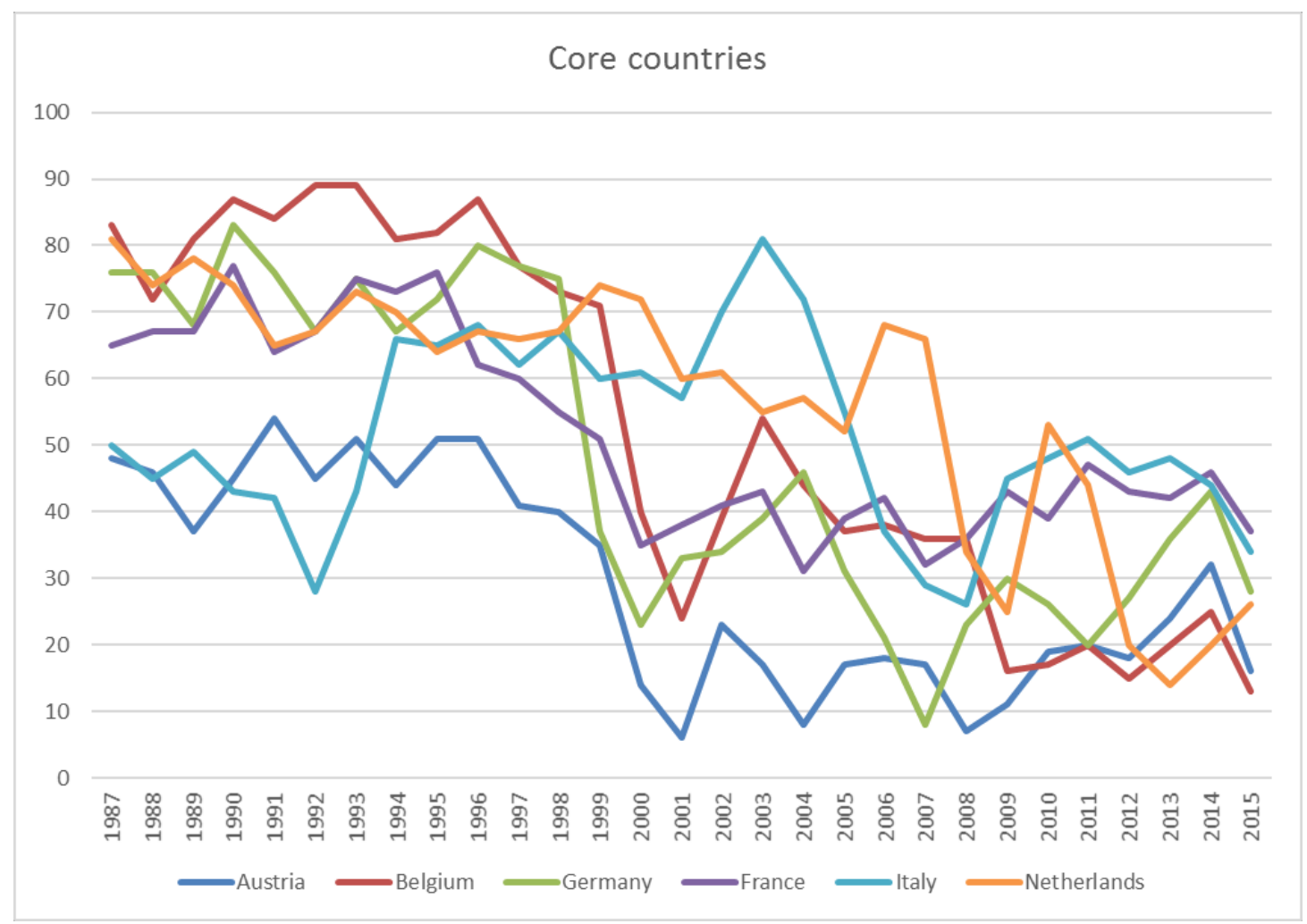


The group of countries we call periphery is shown in Figure 5. Not only these five countries all have very high levels of $N O R D$, they do so throughout. In other words, their scores are consistently above the 50\% mark and these scores are worrisomely trendless. They provide strong, albeit somewhat qualified, confirmation of Bayoumi and Eichengreen (1993) famous early warning about the EMU, specifically about the possibility of an entrenched core and periphery pattern driven by the latter being deep-seated. It is noteworthy that neither Norway nor Switzerland are eurozone countries, although Portugal, Finland and Ireland are.

Figure 5.

NORD for periphery countries, 1990-2015 (Core-periphery dynamics)

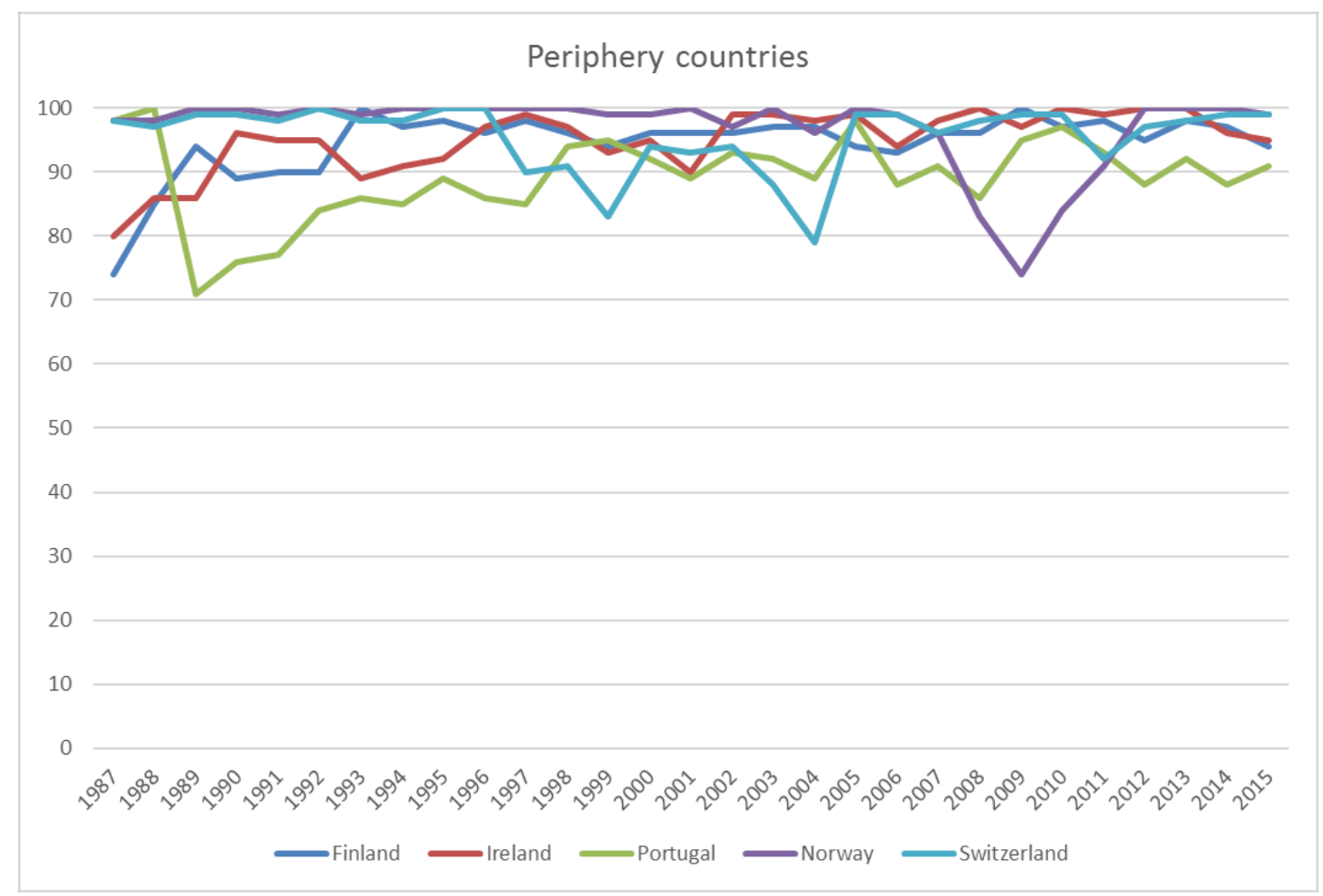

The Philips-Sul procedure also identifies an intermediary or mixed set of countries. Within this group, one distinguishes between two main sub-sets: one for which NORD does not seem to show any clear trends between 1987 and 2015, and another one for which it does. Figure 6 shows that the UK and Denmark are good candidates for the intermediate set. Yet, while Denmark's 
NORD barely moves over time, the opposite can be observed for the UK, displaying high volatility in and out of the core.

\section{Figure 6.}

NORD for intermediary countries, 1990-2015 (Core-periphery dynamics)

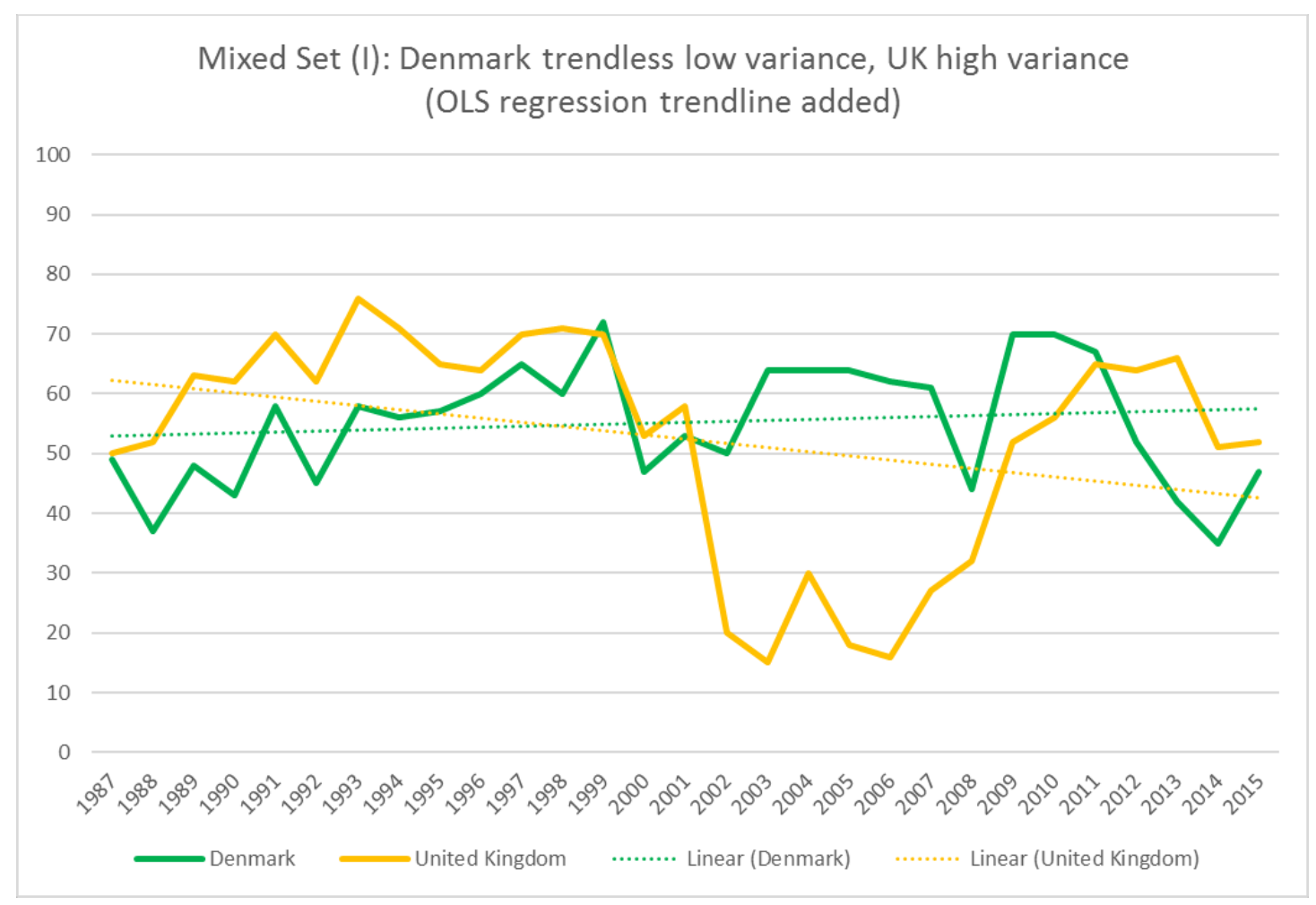

Figure 7 shows the remaining three countries, those at intermediate levels of NORD but with clearly distinguishable trends instead. Here, Spain's NORD is basically flat until 1999 and starts to decline fast afterwards, clearly moving towards the core (linear interpolation suggests it may enter circa 2020.) On the other hand, Greece and Sweden distinctively move away from the core. In other words, they become more peripheral over time. It is interesting to note, however, that between the introduction of the euro in 1999 and the onset of the financial crisis in 2007, Greece was instead moving in the "right direction," that is, towards the core. 
Figure 7.

NORD for intermediary countries, 1990-2015 (Core-periphery dynamics)

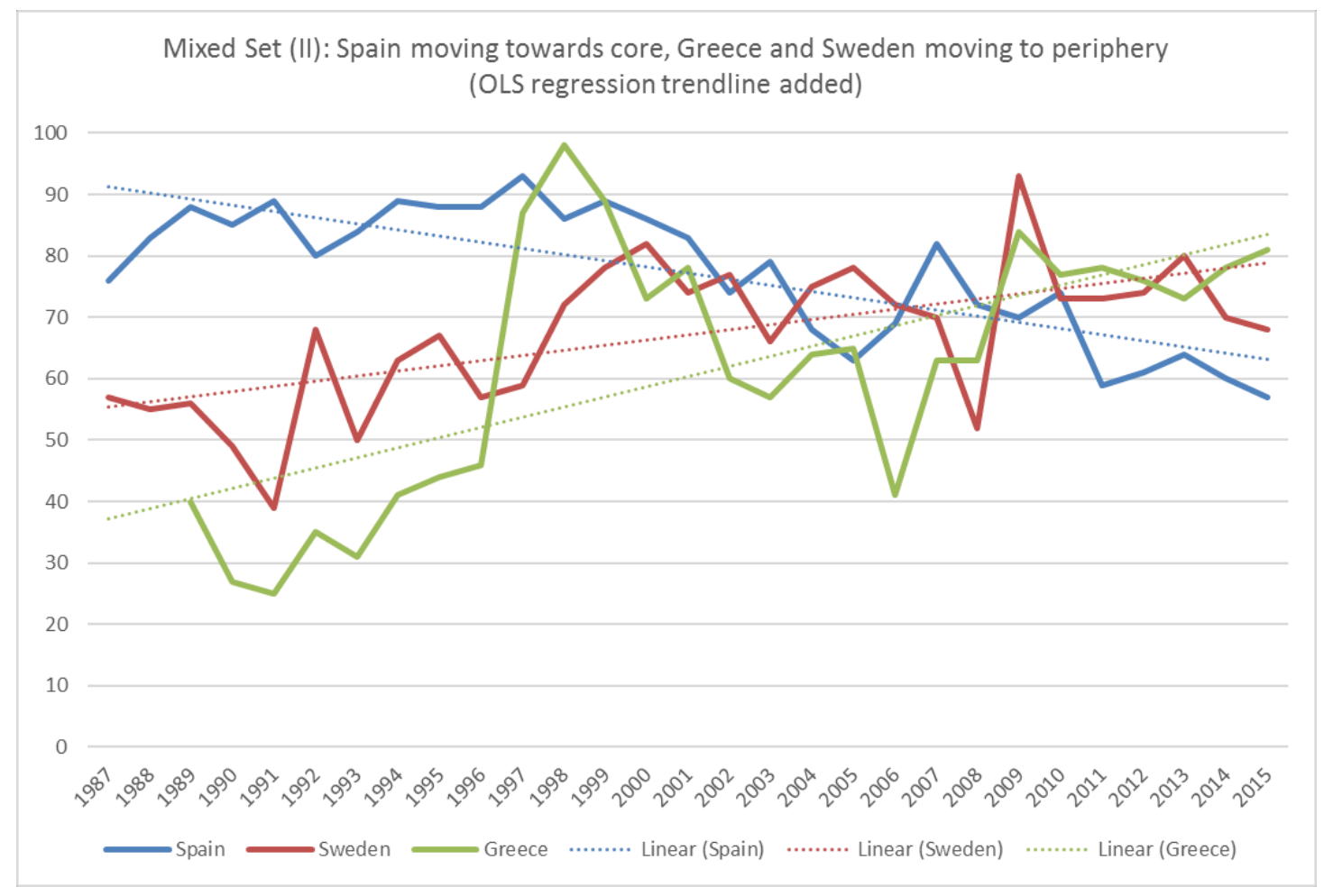

In summary, the results above reveal that the core and periphery pattern has changed considerably since the late 1980s, both in terms of relative strengths and distances between main groups of countries but also in terms of the trajectories of individual countries (for instance, it is interesting to see how different countries join the core at different points in time.) Overall, our new theory-based index, NORD, can be seen to decreases over time for the set of countries that the Philips and Sul (2007) procedure single out and that we call "core" (a result which broadly confirms endogenous OCA predictions), it remains high and basically constant for a more peripheral group (worrisomely confirming Bayoumi and Eichengreen's warning about a deep-seated periphery), and it varies substantially for a mixed set of countries between 1987 and 2015. Denmark's NORD remains constant around the 50\% mark while the UK's score over time makes it move in and out of the core. The results for Spain are quite optimistic as they show that although the country should still be classified as periphery, it is moving towards the core. This is in contrast to two 
much more worrisome trends: according to their NORD scores, Greece and Sweden are slowly moving away from the core group of countries, or in other words, gradually becoming more and more peripheral in the EMU.

\section{Evaluating NORD ("Number of rejections dynamics")}

The objective of this section is to assess our new theory-based continuous measure of the probability of a country being classified as periphery (NORD above 50\%). Given data availability, we produced this index for 16 European countries on a yearly basis between 1987 and 2015.

In order to shed light on the behaviour of NORD across countries and over time, we draw from OCA theory (De Grauwe 2016) and enlist a standard set of candidate explanatory variables. One first group refers to explanatory variables on the fiscal side (Martin and Philippon 2017). The expectation, in this case, is that countries for which debt to GDP ratios and cyclically adjusted budget balances are larger, should be more likely to be classified as periphery.

A second group of explanatory variables focuses on financial links, more specifically we use corporate bond spreads, 10-year government bond spreads, 3-month interbank interest rate spreads, average consumer loan interest rate spreads, and returns on equity differential. All spreads are computed vis-à-vis Germany. This set of financial variables is consistent with the European Central Bank's definitions of financial integration (ECB 2017, Spiegel 2009). Our prior in this case is that the more financially integrated an individual country is with the rest of the EU in a given year, the more likely it will not be classified as pertaining to the periphery.

A third group of variables we use to assess the validity of our index covers external links, in particular, the roles of foreign direct investment (FDI) inflows, 
the real effective exchange rate, and trade openness (Rose 2000, Brouwer et al. 2008). Note that, in this latter case, we examine the potentially different roles of the shares of exports and imports over GDP. Our expectation here is that larger the inflows of FDI, increases in the real exchange rate or in the share of imports plus exports in GDP will, all else equal, make a country less likely to be classified as periphery.

The fourth and last main group of explanatory variables we draw upon in order to try to evaluate NORD regards structural reforms. Here we use OECD data on employment protection legislation (EPL), covering both permanent and temporary contracts (Boeri and Garibaldi 2006), and on product markets regulation (PMR-overall economy). Our expectation is that the more extensive reforms different countries have implemented, the more likely is that they will not be classified as periphery. In other words, the more protective is employment legislation and the more extensive are product regulations, the more likely the country can be classified as peripheral.

We include a dummy variable for euro area membership in all specifications as suggested by the results from the Philips-Sul procedure presented in the previous section. Eurozone membership takes the values of one for countries joining the EMU starting from accession year.

The estimation sample includes Austria, Belgium, Germany, Spain, Finland, France, Greece, Ireland, Italy, the Netherland, Portugal, plus three EU non-euro area countries (Denmark, Sweden and UK) and two countries that are not EU members (Switzerland and Norway). We present the results for the period 1990-2015. 
In order to address possible endogeneity and omitted variables problems, we employ a GMM approach where the weighting matrix is set to equal the 2SLS. ${ }^{4}$ In the estimation, the number of endogenous variables equals the number of instruments, where we select the instruments to be the lagged dependent variables, the constant and the Eurozone (EZ) membership dummy. This choice also addresses concerns about the instrument proliferation issue in GMM (Roodman, 2009).

Table 1 shows our baseline results. We include a dummy variable capturing membership in the Eurozone throughout and its coefficient is always statistically significant and carrying the expected negative sign. It suggests EZ membership is associated with a smaller probability of being classified as periphery. The first column also shows two important fiscal variables: countries with higher debt to GDP ratios and cyclically adjusted budget balances are more likely to be classified as periphery (as these are positively associated with NORD). Regarding financial integration, notice that only one of the four aspects we account for turns out to be statistically significant, namely inter-bank spreads. Regarding external linkages, the coefficients on both foreign direct investment inflows and the real exchange rate carry the expected negative signs and are statistically significant (we confirm below that the FDI result is comparatively more robust.) Everything else the same, lower values of NORD are associated with countries receiving higher inflows of foreign investment. The results in column (4) for trade openness show that the larger the share of the sum of exports and imports over GDP, the less likely the country is to be classified as periphery. Globalisation, in this sense, helps countries to avoid being at the margins. The column (5) has results for two

4 The results are qualitatively the same if instead we use a Huber/Eicker/White heteroskedasticity-robust variance-covariance matrix (these are available upon request from the authors). 
structural reforms that have played a big role in the debate so far on Eurozone imbalances and they both seem to support NORD as a satisfactory measure. They show that the more protective is employment legislation and the more regulated are the product markets, the higher is the probability of a country being classified as periphery. Overall, these results are strongly supportive of NORD as a continuous measure of the probability of a country being classified as periphery. There are, simply put, no unexpected or counter-intuitive results.

The overall results (last column in Table 1) suggest that a strong role is played by membership in the Eurozone and by the strictness of product market regulation, whereby a high PMR increases the likelihood of being classified as periphery. ${ }^{5}$ On balance, this set of results strongly support NORD as a continuous time-variant measure of the likelihood of a country being in the periphery. Membership of the currency union, for the countries in our sample, suggests an important role in making countries less "peripheral", with this reduction of likelihood of being classified in the periphery to core being as much as 16 percentage points. ${ }^{6}$

\footnotetext{
${ }^{5}$ This is, in turn, not surprising given that our index is based on supply side dynamics and the extent to which those prompt similar GDP reactions among member states.

${ }^{6}$ The results for the EA membership and PMR remain robust when the EA dummy is set to start in 2002 , i.e. the year when euro coins were effectively introduced (see Appendix 5).
} 
Table 1.

The Determinants of NORD

(16 countries, 1991-2015)

\begin{tabular}{|c|c|c|c|c|c|c|}
\hline & $\begin{array}{c}(1) \\
\text { Fiscal }\end{array}$ & $\begin{array}{c}(2) \\
\text { Financial }\end{array}$ & $\begin{array}{c}(3) \\
\text { External }\end{array}$ & $\begin{array}{c}(4) \\
\text { Trade }\end{array}$ & $\begin{array}{c}\text { (5) } \\
\text { Reforms }\end{array}$ & $\begin{array}{l}(6) \\
\text { All }\end{array}$ \\
\hline Debt/GDP & $\begin{array}{l}0.118^{* * *} \\
(0.042)\end{array}$ & & & & & $\begin{array}{c}0.090 \\
(0.141)\end{array}$ \\
\hline Adj. Budget Balance & $\begin{array}{l}0.836^{* *} \\
(0.336)\end{array}$ & & & & & $\begin{array}{l}1.629^{*} \\
(0.965)\end{array}$ \\
\hline Corporate bond spread & & $\begin{array}{c}0.484 \\
(0.617)\end{array}$ & & & & $\begin{array}{c}0.701 \\
(0.679)\end{array}$ \\
\hline $\begin{array}{l}\text { 3-month interbank } \\
\text { spread }\end{array}$ & & $\begin{array}{c}-4.455^{* * *} \\
(1.435)\end{array}$ & & & & $\begin{array}{c}-0.760 \\
(2.742)\end{array}$ \\
\hline $\begin{array}{l}\text { Avg on consumer loans } \\
\text { spread }\end{array}$ & & $\begin{array}{l}-0.200 \\
(0.479)\end{array}$ & & & & $\begin{array}{c}-0.360 \\
(0.866)\end{array}$ \\
\hline Return on equity diff. & & $\begin{array}{c}0.634 \\
(0.438)\end{array}$ & & & & $\begin{array}{l}-0.623 \\
(0.397)\end{array}$ \\
\hline FDI & & & $\begin{array}{c}-0.479^{* * *} \\
(0.152)\end{array}$ & & & $\begin{array}{l}-0.419^{* *} \\
(0.202)\end{array}$ \\
\hline Reer (CPI adj.) & & & $\begin{array}{c}-0.240^{* *} \\
(0.118)\end{array}$ & & & $\begin{array}{l}-0.492^{*} \\
(0.294)\end{array}$ \\
\hline Trade openness (\%GDP) & & & & $\begin{array}{c}-0.135^{* *} \\
(0.065)\end{array}$ & & $\begin{array}{c}-0.457^{* *} \\
(0.191)\end{array}$ \\
\hline EPL temporary & & & & & $\begin{array}{c}5.300^{* * *} \\
(1.871)\end{array}$ & $\begin{array}{c}4.468 \\
(3.856)\end{array}$ \\
\hline PMR & & & & & $\begin{array}{l}6.898^{*} \\
(3.537)\end{array}$ & $\begin{array}{c}1.906 \\
(6.872)\end{array}$ \\
\hline $\begin{array}{l}\text { Eurozone membership } \\
\text { dummy } \\
\text { (1999) }\end{array}$ & $\begin{array}{c}-19.284^{* * *} \\
(2.105)\end{array}$ & $\begin{array}{c}-28.330^{* * *} \\
(3.160)\end{array}$ & $\begin{array}{c}-12.038^{* * *} \\
(1.935)\end{array}$ & $\begin{array}{c}-11.612^{* * *} \\
(2.155)\end{array}$ & $\begin{array}{c}-8.911^{* * *} \\
(3.199)\end{array}$ & $\begin{array}{c}-15.363^{* *} \\
(6.243)\end{array}$ \\
\hline $\mathrm{C}$ & $\begin{array}{c}69.516^{* * *} \\
(3.135)\end{array}$ & $\begin{array}{c}82.239^{* * *} \\
(2.252)\end{array}$ & $\begin{array}{c}98.345^{* * *} \\
(11.891)\end{array}$ & $\begin{array}{c}82.566^{* * *} \\
(4.693)\end{array}$ & $\begin{array}{c}49.242^{* * *} \\
(7.951)\end{array}$ & $\begin{array}{c}147.812^{* * *} \\
(45.754)\end{array}$ \\
\hline Adj-R2 & 0.748 & 0.679 & & 0.710 & 0.790 & 0.702 \\
\hline Durbin-Watson & 0.577 & 0.970 & 0.544 & 0.465 & 0.717 & 1.369 \\
\hline J-Stat (p-value) & $(0.000)$ & $(0.000)$ & $(0.000)$ & $(0.000)$ & $(0.000)$ & $(0.000)$ \\
\hline
\end{tabular}

These overall findings are in line with the idea that one of the main concerns in terms of monetary union membership would be again represented by the costs of adjustment in order to deal with asymmetries. In the absence of sufficient 
labor flexibility, and equally of fiscal transfers at the euro-area level, many countries suffer from severe adjustment problems. As the crisis made clear, the lack of such channels, in the presence of asymmetries, has made the cost of adjustment rather high ex post in terms of the preservation of the monetary union.

Table 2 extends our baseline results. Note the coefficient of the dummy variable for Eurozone membership as well as that on foreign direct investment remain significant throughout. These are robust results. The other key result from Table 1 refers to the role of product market regulations (PMR). In Table 2, we further investigate this latter result. Specifically, we study whether the greater competitive pressures created by decreasing regulations in product markets can be somehow captured in different ways. We have in mind the notion that these competitive pressures can somehow be "imported" instead.

The first column of Table 2 suggests that including exports and imports instead of trade openness creates a problem of multicollinearity, as not one of the two coefficients is statistically significant. ${ }^{7}$ When each of these variables is introduce by itself, their coefficients carry the expected sign and are statistically significant. It is also worth noting that the size of the coefficient on imports is substantially larger (indeed almost twice as large) as that on exports. More importantly for our purposes, note that the coefficient on product market regulations is significant only when trade openness, exports or imports are excluded from the specification suggesting that these two sets of variables (trade and reforms) capture similar mechanisms (competition).

${ }^{7}$ This is because of the high pair-wise correlation between these two variables (as shown in correlation matrix in the Appendix, multicollinearity is not a problem for any of the variables we use, except exports, imports and openness.) 
Table 2.

Importing Competition

How Imports/GDP Substitute for PMR regarding NORD

(16 countries, 1991-2015)

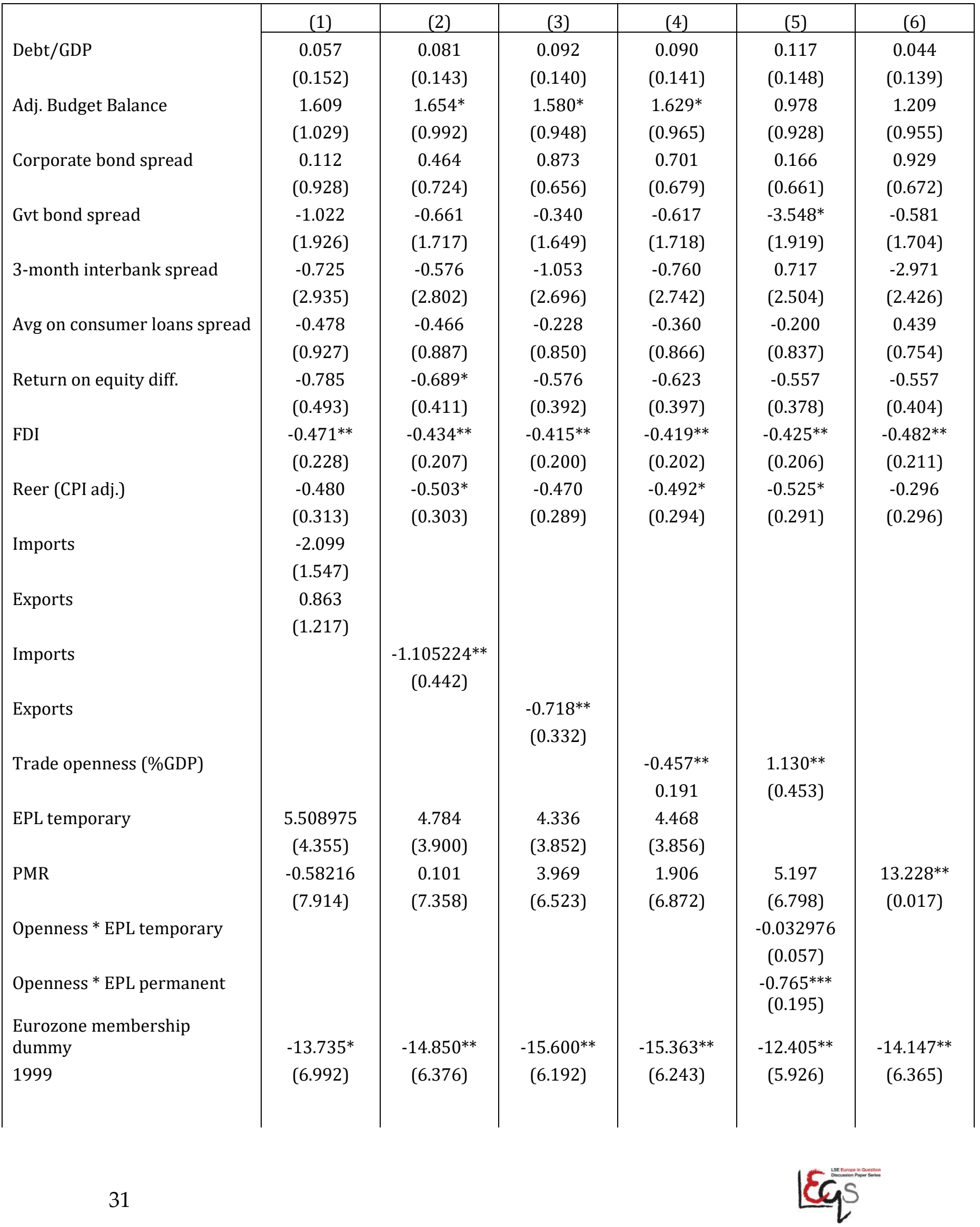


Symmetry and Convergence in Monetary Unions

\begin{tabular}{|l|c|c|c|c|c|c|}
$\mathrm{C}$ & $\begin{array}{c}158.885^{* * *} \\
(51.121)\end{array}$ & $\begin{array}{c}157.706^{* * *} \\
(48.545)\end{array}$ & $\begin{array}{c}135.533^{* *} \\
(43.761)\end{array}$ & $\begin{array}{c}147.812^{* * *} \\
(45.754)\end{array}$ & $\begin{array}{c}166.534^{* * *} \\
(43.135)\end{array}$ & $\begin{array}{c}73.414^{*} \\
(37.856)\end{array}$ \\
\hline & & & & & & \\
Adj-R2 & 0.658 & 0.688 & 0.708 & 0.702 & 0.717 & 0.691 \\
Durbin-Watson & 1.462 & 1.408 & 1.341 & 1.369 & 1.360 & 1.324 \\
J-Stat (p-value) & $(0.000)$ & $(0.000)$ & $(0.000)$ & $(0.000)$ & $(0.000)$ & $(0.000)$ \\
\hline
\end{tabular}

Finally, we have also investigated whether the effects of PMR would be identifiable if we account for possible interactions between trade openness and two different aspects of employment protection legislation (covering either permanent or temporary contracts) and, as it can be seen from the Table, this does not help to further isolate the effects of PMR (as its coefficient remains statistically insignificant).

Table 3 provides an important robustness check on the results above. The Global Financial Crisis that started in 2007 and that affected Europe in full in 2010 (becoming the Eurozone Sovereign Debt Crisis) by its very nature generated a similar response across countries. The extent of symmetry increased rapidly and broadly so one may be justifiably concerned that this would affect our results. Table 3 shows the simplest test for this idea, namely, of whether splitting the sample in 2010 (or in 2007) substantially affect our baseline results for NORD. As it is clear from the Table, that does not seem to be the case. Some coefficients loose statistical significance but our main individual results remain intact and the broad pattern of signs does not seem to have changed either. Eurozone membership and trade (or reforms) are again key factors. 
Table 3.

How Did the Eurozone Crisis affect NORD Dynamics?

(16 countries, 1991-2010)

\begin{tabular}{|c|c|c|c|c|c|c|}
\hline & Fiscal & Financial & External & Trade & Labour & All \\
\hline Debt/GDP & $\begin{array}{l}0.230^{* * *} \\
(0.085)\end{array}$ & & & & & $\begin{array}{c}0.017 \\
(0.228)\end{array}$ \\
\hline Adj. Budget Balance & $\begin{array}{l}0.958^{* *} \\
(0.414)\end{array}$ & & & & & $\begin{array}{l}-0.398 \\
(1.765)\end{array}$ \\
\hline Corporate bond spread & & $\begin{array}{l}-0.158 \\
(0.623)\end{array}$ & & & & $\begin{array}{c}0.794 \\
(0.846)\end{array}$ \\
\hline Gvt bond spread & & $\begin{array}{c}2.465 \\
(2.683)\end{array}$ & & & & $\begin{array}{l}-8.156 \\
(5.929)\end{array}$ \\
\hline 3-month interbank spread & & $\begin{array}{l}-4.955^{* *} \\
(2.106)\end{array}$ & & & & $\begin{array}{c}2.741 \\
(5.042)\end{array}$ \\
\hline $\begin{array}{l}\text { Avg on consumer loans } \\
\text { spread }\end{array}$ & & $\begin{array}{l}-0.026 \\
(0.506)\end{array}$ & & & & $\begin{array}{c}0.383 \\
(1.194)\end{array}$ \\
\hline Return on equity diff. & & $\begin{array}{c}0.519 \\
(0.418)\end{array}$ & & & & $\begin{array}{l}-0.805 \\
(0.611)\end{array}$ \\
\hline FDI & & & $\begin{array}{c}-0.626^{* * *} \\
(0.181)\end{array}$ & & & $\begin{array}{l}-0.370 \\
(0.248)\end{array}$ \\
\hline Reer (CPI adj.) & & & $\begin{array}{c}-0.308^{* *} \\
(0.129)\end{array}$ & & & $\begin{array}{l}-0.820^{*} \\
(0.462)\end{array}$ \\
\hline Trade openness (\%GDP) & & & & $\begin{array}{l}-0.041 \\
(0.096)\end{array}$ & & $\begin{array}{l}-0.436 \\
(0.385)\end{array}$ \\
\hline EPL temporary & & & & & $\begin{array}{c}6.008^{* * *} \\
(2.085)\end{array}$ & $\begin{array}{c}2.902 \\
(4.346)\end{array}$ \\
\hline PMR & & & & & $\begin{array}{l}8.987^{* *} \\
(4.246)\end{array}$ & $\begin{array}{c}-1.073 \\
(12.158)\end{array}$ \\
\hline $\begin{array}{l}\text { Eurozone membership } \\
\text { dummy } \\
1999\end{array}$ & $\begin{array}{c}-16.89^{* * *} \\
(2.213)\end{array}$ & $\begin{array}{c}-25.437^{* * *} \\
(3.289)\end{array}$ & $\begin{array}{c}-9.655^{* * *} \\
(2.187)\end{array}$ & $\begin{array}{c}-12.62^{* * *} \\
(2.409)\end{array}$ & $\begin{array}{c}-7.104^{* *} \\
(3.389)\end{array}$ & $\begin{array}{c}-14.613^{* *} \\
(7.170)\end{array}$ \\
\hline $\mathrm{C}$ & $\begin{array}{c}62.510^{* * *} \\
(5.132)\end{array}$ & $\begin{array}{c}79.559^{* * *} \\
(2.004)\end{array}$ & $\begin{array}{c}105.507^{* * *} \\
(13.000)\end{array}$ & $\begin{array}{c}75.848^{* * *} \\
(6.734)\end{array}$ & $\begin{array}{c}43.183^{* * *} \\
(9.280)\end{array}$ & $\begin{array}{r}185.747^{* *} \\
(79.816)\end{array}$ \\
\hline Adj-R2 & 0.729 & 0.677 & 0.659 & 0.693 & 0.785 & 0.605 \\
\hline Durbin-Watson & 0.643 & 1.018 & 0.684 & 0.535 & 0.823 & 1.509 \\
\hline J-Stat (p-value) & $(0.000)$ & $(0.000)$ & $(0.000)$ & $(0.000)$ & $(0.000)$ & $(0.000)$ \\
\hline
\end{tabular}


Symmetry and Convergence in Monetary Unions

One remaining important concern regards the robustness and magnitude of the effect of Euro membership. One way of further investigating this issue is to reestimate the specifications in Table 1 using the differences-in-differences estimator. This estimator requires that euro membership is modelled as the treatment. The introduction of the euro took place between 1999 and 2002 when twelve European countries started using the single currency. ${ }^{8}$ The main coefficient of interest is the interaction between time and the dummy for Eurozone membership. As it can be seen, this coefficient is significant throughout and carries the expected negative sign. Adoption of the single currency, everything else equal, makes the probability of countries being classified as core significantly larger. This coefficient can be interpreted as showing that the "pure" effect of Eurozone membership is to decrease the likelihood that a country is classified as periphery by about 10 (ten) percentage points. In light of the role played by the various other factors suggested by OCA theory, this is a non-trivial and sensible estimate in our view.

\footnotetext{
${ }^{8}$ The next country to join was Slovenia in 2017, followed by Slovakia in 2009, Estonia in 2011, Latvia in 2014 and Lithuania in 2015. However, because all of these were communist countries before 1990, data required for our exercise is not available as it does not go back to 1990 .
} 
Table 4.

Difference in Differences Evidence on the Effects of Euro Membership on the Dynamics of NORD

(16 countries, 1991-2015)

\begin{tabular}{|c|c|c|c|c|c|c|}
\hline & (1) & (2) & (3) & (4) & (5) & (6) \\
\hline & Fiscal & Financial & External & Trade & Labour & All \\
\hline Time & $\begin{array}{l}-0.231 \\
(0.159)\end{array}$ & $\begin{array}{c}-0.324^{* * *} \\
(0.168)\end{array}$ & $\begin{array}{c}0.075 \\
(0.127)\end{array}$ & $\begin{array}{c}0.187 \\
(0.151)\end{array}$ & $\begin{array}{l}-0.276 \\
(0.287)\end{array}$ & $\begin{array}{l}-0.041 \\
(0.371)\end{array}$ \\
\hline Time*EZ membership & $\begin{array}{c}-1.093^{* * *} \\
(0.282)\end{array}$ & $\begin{array}{l}-0.673^{*} \\
(0.260)\end{array}$ & $\begin{array}{c}-0.744^{* * *} \\
(0.245)\end{array}$ & $\begin{array}{c}-0.744^{* * *} \\
(0.245)\end{array}$ & $\begin{array}{l}-0.585^{*} \\
(0.310)\end{array}$ & $\begin{array}{l}-0.851^{* *} \\
(0.364)\end{array}$ \\
\hline Debt/GDP & $\begin{array}{l}0.260^{* * *} \\
(0.044)\end{array}$ & & & & & $\begin{array}{l}0.135^{* *} \\
(0.066)\end{array}$ \\
\hline Adj. Budget Balance & $\begin{array}{c}0.729^{* * *} \\
(0.260)\end{array}$ & & & & & $\begin{array}{c}0.342 \\
(0.315)\end{array}$ \\
\hline Corporate bond spread & & $\begin{array}{c}0.053 \\
(0.360)\end{array}$ & & & & $\begin{array}{c}0.307 \\
(0.441)\end{array}$ \\
\hline Gvt bond spread & & $\begin{array}{l}0.787^{*} \\
(0.435)\end{array}$ & & & & $\begin{array}{c}0.294 \\
(0.566)\end{array}$ \\
\hline 3-month interbank spread & & $\begin{array}{c}-2.758^{* * *} \\
(0.764)\end{array}$ & & & & $\begin{array}{l}-1.496 \\
(1.224)\end{array}$ \\
\hline Avg on consumer loans spread & & $\begin{array}{l}-0.487 * \\
(0.271)\end{array}$ & & & & $\begin{array}{l}-0.549 \\
(0.461)\end{array}$ \\
\hline Return on equity diff. & & $\begin{array}{c}0.006 \\
(0.004)\end{array}$ & & & & $\begin{array}{l}-0.034 \\
(0.056)\end{array}$ \\
\hline FDI & & & $\begin{array}{l}-0.038 \\
(0.072)\end{array}$ & & & $\begin{array}{c}0.041 \\
(0.071)\end{array}$ \\
\hline Reer (CPI adj.) & & & $\begin{array}{l}-0.147 \\
(0.091)\end{array}$ & & & $\begin{array}{l}-0.255^{*} \\
(0.151)\end{array}$ \\
\hline Trade openness (\%GDP) & & & & $\begin{array}{l}-0.094 \\
(0.075)\end{array}$ & & $\begin{array}{l}-0.269^{* *} \\
(0.108)\end{array}$ \\
\hline EPL temporary & & & & & $\begin{array}{c}1.800 \\
(1.641)\end{array}$ & $\begin{array}{c}0.314 \\
(1.930)\end{array}$ \\
\hline PMR & & & & & $\begin{array}{l}-3.960 \\
(4.590)\end{array}$ & $\begin{array}{l}-2.295 \\
(4.964)\end{array}$ \\
\hline $\begin{array}{l}\text { Eurozone membership } \\
\text { dummy } \\
1999\end{array}$ & $\begin{array}{c}4.574 \\
(5.116)\end{array}$ & $\begin{array}{c}-11.604^{* *} \\
(4.877)\end{array}$ & $\begin{array}{l}-0.973 \\
(4.665)\end{array}$ & $\begin{array}{l}-0.196 \\
(4.518)\end{array}$ & $\begin{array}{l}-3.748 \\
(5.317)\end{array}$ & $\begin{array}{c}-11.643^{*} \\
(6.684)\end{array}$ \\
\hline $\mathrm{C}$ & $\begin{array}{c}62.573^{* * *} \\
(3.638)\end{array}$ & $\begin{array}{c}84.011^{* * *} \\
(2.511)\end{array}$ & $\begin{array}{l}87.293 \\
(9.355)\end{array}$ & $\begin{array}{c}78.055^{* * *} \\
(4.738)\end{array}$ & $\begin{array}{c}81.737^{* * *} \\
(12.946)\end{array}$ & $\begin{array}{c}122.577^{* * *} \\
(23.234)\end{array}$ \\
\hline Adj-R2 & 0.758 & 0.793 & 0.709 & 0.709 & 0.784 & 0.819 \\
\hline Durbin-Watson & 0.564 & 0.807 & 0.471 & 0.459 & 0.664 & 0.948 \\
\hline J-Stat (p-value) & $(0.000)$ & $(0.000)$ & $(0.000)$ & $(0.000)$ & $(0.000)$ & $(0.000)$ \\
\hline
\end{tabular}


To conclude, this section has shown a sequence of results intended to check whether NORD can be said to be satisfactory as a continuous time-variant measure of the likelihood of a country being classified in the periphery or in the core. The associations we uncover are all intuitive and in extremely few cases we encounter results that are not sensible. The role of Eurozone membership behaves according to the predictions from endogenous OCA theory (Frankel and Rose, 1998). The results for foreign investment inflows and trade openness (or otherwise product market regulations) are also very much in line with OCA theoretical predictions (De Grauwe 2016). The results for fiscal and financial liberalisation variables are equally judicious and accord to theoretical priors, despite not being as robust as for other variables. The main results we obtain for NORD are also not affected by splitting the sample in before and after the Eurozone crisis of 2010, by using different estimators (like logit or OLS), variations on the measurement of the key variables (such as using 2002 for the Eurozone dummy) and the use of standard differences-indifferences. In sum, these results should give one confidence that NORD is a more than adequate continuous time-variant measure of the likelihood of a country being classified as periphery and as such should be given the chance to be further investigated and developed.

\section{Conclusions}

The objective of this paper is to attempt to further our understanding of symmetry and its dynamics in currency unions, specifically in the context of the European Economic and Monetary Union. One main concern was to try to go beyond the mainly static and binary ways of framing this issue. We put forward a new simple theory-based measure that we think can successfully locate countries in a core-periphery continuum. We construct such measure for 
a set of 16 European countries yearly from 1987 to 2015 and provided an assessment, based on the endogenous OCA theory, of the main potential underlying explanatory factors of the dynamics of this measure over time and across countries.

Our main conclusion is that this new theory-based measure allows us to clearly identify three clear sets of countries on the basis not only of the level of our new measure but also in terms of its dynamic behaviour. Using the Phillips-Sul (2007) testing procedure, we show the emergence a newer set of core countries (composed by Austria, Belgium, Germany, France, Italy and Netherlands), a mixed set of countries (namely Denmark, Sweden, Greece, Spain and the UK), and a set of deep-rooted periphery countries (Finland, Ireland, Norway, Portugal, and Switzerland).

There are valuable lessons from the dynamics of this measure. Our findings suggest that the irreversibility of being in the core should not be taken for granted. Our index increases for core countries (which confirms endogenous OCA predictions), remains worrisomely constant for a periphery, and varies substantially for the intermediate set of countries. Spain (Sweden and Greece) becomes consistently more (less) core over time, Denmark's remains constant and the UK moves in and out of core over time. Our panel estimates on a specification suggested by endogenous OCA theory imply that euro membership and stricter product market regulations (or trade openness) make countries more or less likely to be in the core, respectively. The analysis presented here documents that the introduction of the single currency preceded a substantial increase in symmetry among member states, thus improving the stability of the Euro Area. 


\section{References}

Alesina, A. \& R. Barro (2002), "Currency Unions”, Quarterly Journal of Economics, 117 (2): 409-436.

Arestis, P. \& P. Phelps (2016), "Endogeneity Analysis of Output Synchronization in the Current and Prospective EMU," Journal of Common Market Studies, 54 (3): 525-543.

Artis, M. \& W. Zhang (2001), "Core and Periphery in EMU: A Cluster Analysis," Economic Issues 6(2): 47-58.

Basse, T. (2014), "Searching for the EMU Core Member Countries," European Journal of Political Economy 34 (1): 32-39.

Bayoumi, T. \& B. Eichengreen (1993), "Shocking Aspects of European Monetary Integration," in F. Giavazzi and F. Torres (eds), Adjustment and Growth in the European Monetary Union, Cambridge University Press.

Bayoumi, T. \& B. Eichengreen (1997), "Ever Closer to Heaven? An optimum-currencyarea index for European countries," European Economic Review, 41(3): 761-770.

Begg, I. (2015). “Genuine Economic and Monetary Union” in S. Durlauf and L. Blume (eds), The New Palgrave Dictionary of Economics, Palgrave Macmillan.

Blanchard, O. \& D. Quah (1989), "The Dynamic Effects of Aggregate Demand and Aggregate Supply Disturbances," American Economic Review, 79 (5): 655-673

Boeri, T. \& P. Garibaldi (2006), "Are Labour Markets in the New Member States Sufficiently Flexible for EMU?" Journal of Banking and Finance 30 (5): 1393-1407.

Brouwer, J., Paap, R. \& J. Viaene (2008), “The Trade and FDI Effects of EMU Enlargement," Journal of International Money and Finance, 27(2): 188-208.

Campos, N. and C. Macchiarelli (2016), "Core and Periphery in the European Monetary Union: Bayoumi and Eichengreen 25 years later," Economics Letters, 147(1): 127130.

Chari V.V., Dovis, A. \& P. Kehoe (2015), “Rethinking Optimal Currency Areas”, Federal Reserve Bank of Minneapolis, Research Department Staff Report.

De Grauwe, P. (2016) The Economics of Monetary Unions, Oxford: Oxford University Press.

De Grauwe, P. \& F. Mongelli (2005), "Endogeneities of Optimum Currency Areas. What Brings Countries Sharing a Single Currency Closer Together?” ECB Working Paper No. 468, April.

De Haan, J., Inklaar, R. \& R. Jong-A-Pin (2008), "Will business cycles in the euro area converge? A critical survey of empirical research," Journal of Economic Surveys, 22(2): 234-273.

European Central Bank (2017), Financial Integration in Europe, Frankfurt: ECB.

Farhi, E. \& I. Werning, (2015), "Labor Mobility in Currency Unions," MIT mimeo.

Frankel, J. \& A. Rose (1998), "The Endogeneity of the Optimum Currency Area Criteria," Economic Journal, 108 (449): 1009-1025.

Glick, R. \& A. Rose (2016), “Currency Unions and Trade: A Post-EMU Mea Culpa," mimeo.

Hendry, D., Johansen, S. \& C. Santos (2008), "Automatic Selection of Indicators in a Fully Saturated Regression,” Computational Statistics 23(2): 317-335. 
Krugman, P. (1993), "Lessons of Massachusetts for EMU," in F. Torres and F. Giavazzi (eds), Adjustment and Growth in the European Monetary Union, Cambridge University Press.

Martin, P. and T. Philippon (2017) "Inspecting the Mechanism: Leverage and the Great Recession in the Eurozone”, American Economic Review 107 (7): 1904-1937.

Phillips, P. and D. Sul (2007), "Transition Modelling and Econometric Convergence Tests." Econometrica 75(6): 1771-1855.

Phillips, P. and D. Sul (2009), "Economic Transition and Growth". Journal of Applied Econometrics, 24(7): 1153-1185.

Ramey, V. (2016), "Macroeconomic Shocks and Their Propagation," in J. Taylor and H. Uhlig (eds.), Handbook of Macroeconomics, Volume 2, Elsevier.

Roodman, D. (2009), "A Note on the Theme of Too Many Instruments," Oxford Bulletin of Economics and Statistics, 71(1), 135-158.

Rose, A.K. (2000) "One Money, One Market: Estimating the Effect of Common Currencies on International Trade," Economic Policy 30 (1): 9-45.

Sandbu, M. (2015). Europe's Orphan: The Future of the Euro and the Politics of Debt. Princeton University Press.

Silva, J. S., \& Tenreyro, S. (2010) “Currency Unions in Prospect and Retrospect." Annual Review of Economics, 2(1): 51-74.

Spiegel, M. (2009), “Monetary and Financial Integration in the EMU: Push or pull?,” Review of International Economics, 17(4): 751-776.

Stiglitz, J. (2016), The Euro: How a Common Currency Threatens the Future of Europe. New York: WW Norton \& Company. 


\section{Appendices}

\section{Appendix 1. Data, Sources and definitions}

Annual data spanning the period 1960 - 2015 were collected from the OECD Annual National Accounts (unless otherwise specified) through Datastream for Austria, Belgium, Germany, Denmark, Spain, Finland, France, Greece, Ireland, Italy, Norway, the Netherland, Portugal, Sweden, Switzerland, and the UK. As in Bayoumi and Eichengreen (1993), Germany is used as a numeraire country.

GDP and its deflator: For each country, growth and inflation were calculated as the first difference of the logarithm of real GDP (OECD base year) and the implicit GDP deflator. In line with BE the deflator was used to measure prices since it reflects the price of output rather than the price of consumption. The series used in the VAR were corrected for different regimes in mean, between 1960-69, for the pre-Bretton Wood, 1984-92 - consistent with the pre-Maastricht period, as well as the British sterling and Italian lira EMS dismissal - and after 2007 (2008-2015).

Debt / GDP : Gross debt (\% of GDP) not seasonally adjusted.

Adj. Budget balance: Cyclically adjusted balance (\% of potential GDP) not seasonally adjusted.

Reer (CPI adj.): Real effective exchange rate based on consumer price index.

3-month interbank: Short-term interest rate (3 month, interbank) seasonally adjusted. For each country, the spread is obtained as the difference of the yield vis à vis Germany.

Gvt bond: Long-term interest rate on government bonds seasonally adjusted. For each country, the spread is obtained as the difference of the yield vis à vis Germany.

Corporate bond: Corporate borrowing rate (avg) not seasonally adjusted. For each country, the spread is obtained as the difference of the yield vis à vis Germany.

Avg on consumer loans: Interest rate - average on consumer loans not seasonally adjusted. For each country, the spread is obtained as the difference of the yield vis à vis Germany. 
Share: Share price index (\%yoy) not seasonally adjusted. For each country, the return on equity is obtained as the difference of the price index growth vis à vis Germany.

FDI: (Balance of Payment) FDI - inward, (\%GDP) not seasonally adjusted

EPL permanent: Strictness of employment protection - individual and collective dismissals (regular contracts). The OECD indicators of employment protection are synthetic indicators of the strictness of regulation on dismissals and the use of temporary contracts. For each year, indicators refer to regulation in force on the 1st of January. For more information and full methodology, see www.oecd.org/employment/protection.

EPL temporary: Strictness of employment protection - temporary contracts. The OECD indicators of employment protection are synthetic indicators of the strictness of regulation on dismissals and the use of temporary contracts. For each year, indicators refer to regulation in force on the 1st of January. For more information and full methodology, see www.oecd.org/employment/protection.

PMR: Product Market Regulation (2013). The indictors measure the economywide regulatory and market environments in (or around) 1998, 2003, 2008 and 2013. The indicators cover formal regulations in the following areas: state control of business enterprises; legal and administrative barriers to entrepreneurship; barriers to international trade and investment. A continuous series is obtained by interpolating the last available observation. 
Appendix 2. Descriptive statistics (common sample)

\begin{tabular}{|c|c|c|c|c|c|c|c|}
\hline & $\begin{array}{c}\text { Adj. } \\
\text { Budget } \\
\text { Balance }\end{array}$ & $\begin{array}{c}\text { Debt / } \\
\text { GDP }\end{array}$ & $\begin{array}{c}\text { Corporate } \\
\text { bond } \\
\text { interest } \\
\text { rate }\end{array}$ & $\begin{array}{l}\text { Gvt bond } \\
\text { interest } \\
\text { rate }\end{array}$ & $\begin{array}{c}\text { 3-month } \\
\text { interbank } \\
\text { interest } \\
\text { rate }\end{array}$ & \begin{tabular}{|c|} 
Avg on \\
consumer \\
loans \\
interest \\
rate
\end{tabular} & $\begin{array}{l}\text { Share } \\
\text { prices }\end{array}$ \\
\hline Mean & -2.761 & 67.641 & 4.682 & 4.788 & 3.173 & 9.225 & 6.839 \\
\hline Median & -2.444 & 60.314 & 4.575 & 4.328 & 3.038 & 8.220 & 9.520 \\
\hline Maximum & 4.354 & 177.677 & 13.420 & 22.498 & 16.202 & 45.330 & 101.320 \\
\hline Minimum & -18.609 & 22.940 & 0.000 & 0.647 & 0.020 & 2.690 & -44.740 \\
\hline Std. Dev. & 3.104 & 29.023 & 2.463 & 2.355 & 2.275 & 5.205 & 22.138 \\
\hline Skewness & -1.059 & 0.927 & 0.616 & 2.972 & 1.621 & 3.418 & 0.120 \\
\hline Kurtosis & 5.753 & 3.554 & 4.762 & 18.224 & 8.304 & 20.477 & 3.238 \\
\hline Jarque-Bera & 142.784 & 44.303 & 54.693 & 3160.626 & 457.303 & 4167.579 & 1.357 \\
\hline Probability & $(0.000)$ & $(0.000)$ & $(0.000)$ & $(0.000)$ & $(0.000)$ & $(0.000)$ & $(0.507)$ \\
\hline Observations & 284 & 284 & 284 & 284 & 284 & 284 & 284 \\
\hline & FDI & $\begin{array}{l}\text { Reer } \\
\text { (CPI } \\
\text { adj.) }\end{array}$ & $\begin{array}{c}\text { Exports / } \\
\text { GDP }\end{array}$ & $\begin{array}{c}\text { Imports } \\
/ G D P\end{array}$ & \begin{tabular}{|c|} 
EPL \\
Permanent \\
contracts
\end{tabular} & $\begin{array}{c}\text { EPL } \\
\text { Temp. } \\
\text { contracts }\end{array}$ & $P M R$ \\
\hline Mean & 6.331 & 99.670 & 43.159 & 40.097 & 2.324 & 1.960 & 1.596 \\
\hline Median & 2.800 & 99.950 & 39.936 & 35.806 & 2.357 & 1.563 & 1.517 \\
\hline Maximum & 124.400 & 125.710 & 106.776 & 89.624 & 4.583 & 4.750 & 2.751 \\
\hline Minimum & -6.750 & 80.930 & 14.287 & 18.640 & 1.095 & 0.250 & 0.915 \\
\hline Std. Dev. & 12.255 & 7.010 & 19.427 & 15.840 & 0.635 & 1.184 & 0.377 \\
\hline Skewness & 5.349 & 0.667 & 1.008 & 1.145 & 0.525 & 0.682 & 1.037 \\
\hline Kurtosis & 41.957 & 4.672 & 3.540 & 3.570 & 4.841 & 2.691 & 4.113 \\
\hline Jarque-Bera & 19313.540 & 54.121 & 51.583 & 65.918 & 53.170 & 23.143 & 65.514 \\
\hline Probability & $(0.000)$ & $(0.000)$ & $(0.000)$ & $(0.000)$ & $(0.000)$ & $(0.000)$ & $(0.000)$ \\
\hline Observations & 284 & 284 & 284 & 284 & 284 & 284 & 284 \\
\hline
\end{tabular}




\section{Appendix 3. Correlation matrix}

\begin{tabular}{|c|c|c|c|c|c|c|c|c|c|c|c|c|c|c|c|}
\hline Correlation & NORD & $\begin{array}{l}\text { Debt/ } \\
\text { GDP }\end{array}$ & $\begin{array}{c}\text { Adj. } \\
\text { Budget } \\
\text { Balance }\end{array}$ & $\begin{array}{c}\text { Avg on } \\
\text { consum } \\
\text { er } \\
\text { loans } \\
\text { spread } \\
\end{array}$ & $\begin{array}{c}\text { Gvt } \\
\text { bond } \\
\text { spread }\end{array}$ & $\begin{array}{l}\text { Return } \\
\text { on } \\
\text { equity } \\
\text { diff. }\end{array}$ & $\begin{array}{c}\text { 3- } \\
\text { month } \\
\text { interba } \\
\text { nk } \\
\text { spread } \\
\end{array}$ & $\begin{array}{l}\text { Exports } \\
\text { (\%GDP) }\end{array}$ & $\begin{array}{l}\text { Imports } \\
\text { (\%GDP) }\end{array}$ & $\begin{array}{c}\text { Trade } \\
\text { openne } \\
\text { ss } \\
\text { (\%GDP) }\end{array}$ & $\begin{array}{l}\text { Reer } \\
\text { (CPI } \\
\text { adj.) }\end{array}$ & FDI & $\begin{array}{l}\text { EPL } \\
\text { perm. }\end{array}$ & $\begin{array}{l}\text { EPL } \\
\text { temp. }\end{array}$ & PMR \\
\hline SORE & 1.000 & & & & & & & & & & & & & & \\
\hline Debt/GDP & -0.236 & 1.000 & & & & & & & & & & & & & \\
\hline Adj. Budget Balance & 0.087 & -0.332 & 1.000 & & & & & & & & & & & & \\
\hline Gvt bond spread & 0.041 & 0.522 & -0.285 & 0.480 & 1.000 & & & & & & & & & & \\
\hline Return on equity diff. & 0.079 & -0.169 & 0.213 & 0.011 & -0.247 & 1.000 & & & & & & & & & \\
\hline 3-month interbank spread & 0.000 & 0.063 & -0.180 & 0.765 & 0.424 & 0.050 & 1.000 & & & & & & & & \\
\hline Exports (\%GDP) & 0.052 & -0.087 & 0.219 & -0.315 & -0.146 & -0.009 & -0.307 & 1.000 & & & & & & & \\
\hline Imports (\%GDP) & -0.016 & 0.036 & 0.126 & -0.211 & -0.097 & -0.079 & -0.299 & 0.954 & 1.000 & & & & & & \\
\hline Trade openness (\%GDP) & 0.022 & -0.032 & 0.179 & -0.272 & -0.125 & -0.041 & -0.307 & 0.991 & 0.986 & 1.000 & & & & & \\
\hline Reer (CPI adj.) & -0.189 & -0.148 & -0.144 & -0.197 & -0.033 & -0.084 & -0.015 & -0.105 & -0.133 & -0.119 & 1.000 & & & & \\
\hline EPL all & 0.018 & 0.143 & -0.170 & 0.258 & 0.120 & 0.004 & 0.129 & -0.346 & -0.249 & -0.306 & -0.139 & -0.110 & 1.000 & & \\
\hline EPL temp. & 0.055 & 0.391 & -0.248 & 0.327 & 0.203 & 0.018 & 0.356 & -0.443 & -0.377 & -0.418 & -0.304 & -0.168 & 0.383 & 1.000 & \\
\hline PMR & 0.278 & -0.124 & 0.054 & 0.112 & -0.101 & 0.116 & 0.095 & -0.091 & -0.131 & -0.110 & -0.185 & -0.048 & 0.138 & 0.421 & 1.000 \\
\hline
\end{tabular}




\section{Appendix 4. Table 1A - Test for over-identifying restrictions' count (\% of bootstrap replications)}

Since we are mostly interested in evaluating the extent to which the number of rejections hold from an OCA point of view and - under the assumption that the euro area is closer to an OCA than the EU or whole Europe itself (see also De Grauwe 2016) - we select the value of $\gamma$ which minimizes the number of rejections as in Campos and Macchiarelli (2016), as illustrated in the Table below.

\begin{tabular}{lccccc}
\hline & $\begin{array}{c}\text { \# of } \\
\text { rejections } \\
\boldsymbol{\gamma}=\mathbf{0 . 1}\end{array}$ & $\begin{array}{c}\text { \# of } \\
\text { rejections } \\
\boldsymbol{\gamma}=\mathbf{0 . 5}\end{array}$ & $\begin{array}{c}\text { \# of } \\
\text { rejections }\end{array}$ & $\begin{array}{c}\text { \# of } \\
\boldsymbol{\gamma}=\mathbf{1}\end{array}$ & $\begin{array}{c}\text { \# of } \\
\boldsymbol{\gamma}=\mathbf{1 . 5}\end{array}$ \\
& & & & & \\
& 100.0 & 66.2 & 17.4 & 53.5 & 83.9 \\
BE & 99.8 & 94.0 & 25.1 & 18.3 & 47.1 \\
DE & 100.0 & 95.6 & 35.5 & 16.2 & 36.8 \\
DK & 99.8 & 99.0 & 74.2 & 35.4 & 21.8 \\
ES & 100.0 & 77.5 & 20.3 & 39.3 & 68.5 \\
FR & 94.6 & 100.0 & 92.5 & 63.5 & 35.8 \\
GR & 100.0 & 100.0 & 98.4 & 86.8 & 64.9 \\
IE & 100.0 & 69.4 & 14.6 & 51.8 & 84.9 \\
IT & 100.0 & 93.7 & 20.2 & 17.3 & 50.0 \\
NL & 100.0 & 99.9 & 89.2 & 53.2 & 24.8 \\
PT & 99.8 & 94.0 & 50.2 & 27.2 & 33.6 \\
UK & & & & & \\
& 99.9 & 86.7 & 30.9 & 32.4 & 54.5 \\
Total largest EZ3 & 99.9 & 88.4 & 21.9 & 25.0 & 55.2 \\
Total largest EZ5 & 99.4 & 88.9 & 50.2 & 46.6 & 53.5 \\
Total EZ9 & 11 & 11 & 4 & 5 & 4 \\
\hline No of countries $>$ threshold & 11 & & & \\
\hline
\end{tabular}

Note: We bootstrap the original VAR residuals in a i.i.d. fashion and generate 10.000 data sets. For each of the 10.000 samples we recalculate the VAR parameters. At each replication, we proceed with the SVAR analysis proposed by Bayoumi and Eichengreen (1993) and further impose the over-identifying restriction by counting the number of rejections. Cut off value is that of a $\chi^{2}(1)$ with probability 0.999 (10.828). The results are robust if this probability is reduced to 0.99 (6.635). The countries for which this restriction is rejected on average more than in $50.5 \%$ of cases are the ones for which the over-identifying restriction is relaxed. For consistency of the results, the number of cases the SVAR does not converge is excluded from the count.

Source: Campos and Macchiarelli (2016) 


\section{Appendix 5. Changing the date for EZ membership (2002)}

The following results replicate the results proposed in Table 1 by changing the date for the euro area dummy from the year of formal introduction (1999 - cf. Table 1) to the date of actual adoption (2002).

\begin{tabular}{|c|c|c|c|c|c|c|}
\hline & \multicolumn{6}{|c|}{$1991-2015$} \\
\hline \multirow[b]{2}{*}{ Debt/GDP } & Fiscal & Financial & External & Trade & Labour & All \\
\hline & $\begin{array}{c}0.139^{* * *} \\
(0.043)\end{array}$ & & & & & $\begin{array}{c}0.136 \\
(0.132)\end{array}$ \\
\hline Adj. Budget & 0.295 & & & & & 1.395 \\
\hline Balance & $(0.332)$ & & & & & (0.997) \\
\hline Corporate bond & & $1.174^{*}$ & & & & 0.706 \\
\hline spread & & $(0.711)$ & & & & $(0.652)$ \\
\hline Gvt bond spread & & 1.211 & & & & -0.432 \\
\hline & & $(0.934)$ & & & & $(1.582)$ \\
\hline 3-month interbank & & $-2.917^{*}$ & & & & 0.877 \\
\hline spread & & $(1.649)$ & & & & $(2.922)$ \\
\hline Avg on consumer & & -0.527 & & & & -0.808 \\
\hline loans spread & & $(0.587)$ & & & & $(0.988)$ \\
\hline Return on equity. & & $0.917^{*}$ & & & & -0.418 \\
\hline diff & & $(0.511)$ & & & & $(0.453)$ \\
\hline FDI & & & $\begin{array}{c}-0.596^{* * *} \\
(0.143)\end{array}$ & & & $\begin{array}{c}-0.543^{* * *} \\
(0.190)\end{array}$ \\
\hline Reer (CPI adj.) & & & $\begin{array}{c}-0.143 \\
(0.120)\end{array}$ & & & $\begin{array}{c}-0.282 \\
(0.265)\end{array}$ \\
\hline $\begin{array}{l}\text { Trade openness } \\
\text { (\%GDP) }\end{array}$ & & & & $\begin{array}{c}-0.165^{* * *} \\
(0.063)\end{array}$ & & $\begin{array}{c}-0.491^{* * *} \\
(0.182)\end{array}$ \\
\hline EPL temporary & & & & & $\begin{array}{c}6.153^{* * *} \\
(1.880)\end{array}$ & $\begin{array}{c}4.809 \\
(4.565)\end{array}$ \\
\hline PMR & & & & & $\begin{array}{l}7.568^{* *} \\
(3.476)\end{array}$ & $\begin{array}{c}1.453 \\
(6.781)\end{array}$ \\
\hline EZ membership & $-15.497^{* * *}$ & $-22.129^{* * *}$ & $-11.756^{* * *}$ & $-10.324^{* * *}$ & $-5.715^{* *}$ & $-9.541 *$ \\
\hline 2002 & $(1.896)$ & (3.139) & $(1.742)$ & $(2.018)$ & $(2.637)$ & $(5.731)$ \\
\hline $\mathrm{C}$ & $\begin{array}{c}63.447^{* * *} \\
(3.061)\end{array}$ & $\begin{array}{c}77.157^{* * *} \\
(2.258)\end{array}$ & $\begin{array}{c}88.323^{* * *} \\
(12.009)\end{array}$ & $\begin{array}{c}83.722^{* * *} \\
(4.618)\end{array}$ & $\begin{array}{c}44.175^{* * *} \\
(7.248)\end{array}$ & $\begin{array}{c}122.460^{* * *} \\
(40.149)\end{array}$ \\
\hline Effect & Fixed & Fixed & Fixed & Fixed & Fixed & Fixed \\
\hline Adj-R2 & 0.739 & 0.560 & 0.669 & 0.708 & 0.785 & 0.727 \\
\hline Durbin-Watson & 0.579 & 1.111 & 0.584 & 0.477 & 0.711 & 1.194 \\
\hline J-Stat (p-value) & $(0.000)$ & $(0.000)$ & $(0.000)$ & $(0.000)$ & $(0.000)$ & $(0.000)$ \\
\hline
\end{tabular}




\section{Appendix 6. Results for Employment Protection Legislation: Temporary vs Permanent}

The results in the Table below compare the results in Table 1 (column (1)) to the results when EPL for regular contract is used (column (2)). In column (3) to (5) we further explore the possible interactions between EPL and imports/exports consistent with the idea that some (non-tradeable) sectors may be displaying larger flexibility than others. Our results below do not display any significant effects when these interaction terms are used.

\begin{tabular}{|c|c|c|c|c|c|}
\hline & (1) & (2) & (3) & (4) & (5) \\
\hline Debt/GDP & $\begin{array}{c}0.090 \\
(0.141)\end{array}$ & $\begin{array}{c}0.147 \\
(0.131)\end{array}$ & $\begin{array}{r}0.117 \\
(0.151)\end{array}$ & $\begin{array}{c}0.128 \\
(0.130)\end{array}$ & $\begin{array}{c}0.131 \\
(0.152)\end{array}$ \\
\hline Adj. Budget Balance & $\begin{array}{l}1.629^{*} \\
(0.965)\end{array}$ & $\begin{array}{c}1.237 \\
(1.147)\end{array}$ & $\begin{array}{r}1.182 \\
(0.924)\end{array}$ & $\begin{array}{c}1.487 \\
(0.928)\end{array}$ & $\begin{array}{c}1.524 \\
(0.941)\end{array}$ \\
\hline Corporate bond spread & $\begin{array}{c}0.701 \\
(0.679)\end{array}$ & $\begin{array}{c}0.448 \\
(0.708)\end{array}$ & $\begin{array}{r}1.176 \\
(0.931)\end{array}$ & $\begin{array}{c}0.221 \\
(0.795)\end{array}$ & $\begin{array}{l}-0.054 \\
(1.018)\end{array}$ \\
\hline Gvt bond spread & $\begin{array}{l}-0.460 \\
(1.669)\end{array}$ & $\begin{array}{l}-2.182 \\
(1.798)\end{array}$ & $\begin{array}{r}-1.104 \\
(2.136)\end{array}$ & $\begin{array}{l}-2.231 \\
(2.014)\end{array}$ & $\begin{array}{l}-2.400 \\
(2.208)\end{array}$ \\
\hline 3-month interbank spread & $\begin{array}{l}-0.760 \\
(2.742)\end{array}$ & $\begin{array}{c}0.675 \\
(2.337)\end{array}$ & $\begin{array}{r}-1.613 \\
(2.348)\end{array}$ & $\begin{array}{c}1.331 \\
(2.348)\end{array}$ & $\begin{array}{c}1.451 \\
(2.565)\end{array}$ \\
\hline $\begin{array}{l}\text { Avg on consumer loans } \\
\text { spread }\end{array}$ & $\begin{array}{l}-0.360 \\
(0.866)\end{array}$ & $\begin{array}{c}-0.371 \\
(0.803)\end{array}$ & $\begin{array}{r}0.196 \\
(0.775)\end{array}$ & $\begin{array}{l}-0.709 \\
(0.751)\end{array}$ & $\begin{array}{l}-0.640 \\
(0.794)\end{array}$ \\
\hline Return on equity diff. & $\begin{array}{l}-0.623 \\
(0.397)\end{array}$ & $\begin{array}{l}-0.593 \\
(0.382)\end{array}$ & $\begin{array}{r}-0.500 \\
(0.396)\end{array}$ & $\begin{array}{l}-0.656 \\
(0.419)\end{array}$ & $\begin{array}{l}-0.634 \\
(0.415)\end{array}$ \\
\hline FDI & $\begin{array}{l}-0.419^{* *} \\
(0.202)\end{array}$ & $\begin{array}{c}-0.423^{* *} \\
(0.198)\end{array}$ & $\begin{array}{r}-0.474^{* *} \\
(0.218)\end{array}$ & $\begin{array}{l}-0.402^{*} \\
(0.207)\end{array}$ & $\begin{array}{l}-0.400^{*} \\
(0.211)\end{array}$ \\
\hline Reer (CPI adj.) & $\begin{array}{l}-0.492^{*} \\
(0.294)\end{array}$ & $\begin{array}{l}-0.487^{*} \\
(0.289)\end{array}$ & $\begin{array}{r}-0.278 \\
(0.294)\end{array}$ & $\begin{array}{l}-0.601^{* *} \\
(0.288)\end{array}$ & $\begin{array}{l}-0.616^{* *} \\
(0.291)\end{array}$ \\
\hline Trade openness (\%GDP) & $\begin{array}{c}-0.457^{* *} \\
(0.191)\end{array}$ & $\begin{array}{c}-0.477^{* *} \\
(0.184)\end{array}$ & & & \\
\hline EPL temporary & $\begin{array}{c}4.468 \\
(3.856)\end{array}$ & & & & \\
\hline EPL permanent & & $\begin{array}{l}-19.657 \\
(19.700)\end{array}$ & & & \\
\hline EPL temporary * Exports & & & $\begin{array}{r}-0.189 \\
(0.446)\end{array}$ & & $\begin{array}{c}0.271 \\
(0.605)\end{array}$ \\
\hline EPL temporary * Imports & & & $\begin{array}{r}0.143 \\
(0.428)\end{array}$ & & $\begin{array}{l}-0.254 \\
(0.593)\end{array}$ \\
\hline EPL permanent * Exports & & & & $\begin{array}{c}-0.179 \\
(0.377)\end{array}$ & $\begin{array}{l}-0.360 \\
(0.512)\end{array}$ \\
\hline EPL permanent * Imports & & & & $\begin{array}{c}-0.498 \\
(0.483)\end{array}$ & $\begin{array}{l}-0.310 \\
(0.582)\end{array}$ \\
\hline
\end{tabular}


Symmetry and Convergence in Monetary Unions

\begin{tabular}{|c|c|c|c|c|c|}
\hline PMR & $\begin{array}{c}1.906 \\
(6.872)\end{array}$ & $\begin{array}{c}2.443 \\
(6.728)\end{array}$ & $\begin{array}{r}14.985^{* * *} \\
(5.488)\end{array}$ & $\begin{array}{l}-1.750 \\
(6.545)\end{array}$ & $\begin{array}{l}-2.525 \\
(6.955)\end{array}$ \\
\hline EZ membership & $-15.363^{* *}$ & $-17.787^{* * *}$ & $-19.739^{* * *}$ & $-15.368^{* * *}$ & $-14.307^{* *}$ \\
\hline 1999 & $(6.243)$ & (5.430) & (5.928) & $(5.656)$ & $(6.150)$ \\
\hline \multirow[t]{2}{*}{$\mathrm{C}$} & $147.812^{* * *}$ & $199.591^{* * *}$ & $81.250^{* * *}$ & $194.549^{* * *}$ & $194.926^{* * *}$ \\
\hline & $(45.754)$ & $(57.976)$ & (36.193) & $(44.349)$ & (44.027) \\
\hline Effect & Fixed & Fixed & Fixed & Fixed & Fixed \\
\hline FiAdj-R2 & 0.748 & 0.715 & 0.704 & 0.713 & 0.717 \\
\hline Durbin-Watson & 0.577 & 1.325 & 1.287 & 1.391 & 1.380 \\
\hline J-Stat (p-value) & $(0.000)$ & $(0.000)$ & $(0.000)$ & $(0.000)$ & $(0.000)$ \\
\hline
\end{tabular}




\section{Appendix 7. Probit results}

The results in Table 1 are replicated using a probit model where $\operatorname{Pr}(\mathrm{NORD}>50 \%)=1$. The results in this table show that our findings are robust to the use of such a model.

\begin{tabular}{|c|c|c|c|c|c|c|}
\hline & \multicolumn{6}{|c|}{ 1991-2015 (Probit) } \\
\hline \multirow[b]{2}{*}{ Debt/GDP } & Fiscal & Financial & External & Trade & Labour & All \\
\hline & $\begin{array}{l}-0.004 \\
(0.002)\end{array}$ & & & & & $\begin{array}{c}-0.022^{* * *} \\
(0.005)\end{array}$ \\
\hline Adj. Budget Balance & $\begin{array}{c}0.037 \\
(0.024)\end{array}$ & & & & & $\begin{array}{l}-0.054^{*} \\
(0.030)\end{array}$ \\
\hline Corporate bond spread & & $\begin{array}{c}0.000 \\
(0.035)\end{array}$ & & & & $\begin{array}{c}0.179^{* * *} \\
(0.055)\end{array}$ \\
\hline Gvt bond spread & & $\begin{array}{l}0.129^{* *} \\
(0.063)\end{array}$ & & & & $\begin{array}{c}0.373^{* * *} \\
(0.084)\end{array}$ \\
\hline 3-month interbank spread & & $\begin{array}{c}-0.324^{* * *} \\
(0.090)\end{array}$ & & & & $\begin{array}{c}-0.523^{* * *} \\
(0.151)\end{array}$ \\
\hline $\begin{array}{l}\text { Avg on consumer loans } \\
\text { spread }\end{array}$ & & $\begin{array}{c}0.033 \\
(0.024)\end{array}$ & & & & $\begin{array}{c}0.032 \\
(0.037)\end{array}$ \\
\hline Return on equity diff. & & $\begin{array}{c}0.005 \\
(0.006)\end{array}$ & & & & $\begin{array}{c}0.006 \\
(0.006)\end{array}$ \\
\hline FDI & & & $\begin{array}{c}0.002 \\
(0.006)\end{array}$ & & & $\begin{array}{c}0.000 \\
(0.008)\end{array}$ \\
\hline Reer (CPI adj.) & & & $\begin{array}{c}-0.015^{* *} \\
(0.007)\end{array}$ & & & $\begin{array}{c}-0.070^{* * *} \\
(0.021)\end{array}$ \\
\hline Trade openness (\%GDP) & & & & $\begin{array}{c}0.003 \\
(0.002)\end{array}$ & & $\begin{array}{c}0.002 \\
(0.003)\end{array}$ \\
\hline EPL temporary & & & & & $\begin{array}{l}-0.018 \\
(0.080)\end{array}$ & $\begin{array}{l}0.273^{* *} \\
(0.124)\end{array}$ \\
\hline PMR & & & & & $\begin{array}{l}0.555^{* *} \\
(0.258)\end{array}$ & $\begin{array}{l}-0.149 \\
(0.367)\end{array}$ \\
\hline $\begin{array}{l}\text { EZ membership } \\
1999\end{array}$ & $\begin{array}{c}-0.887^{* * *} \\
(0.148)\end{array}$ & $\begin{array}{c}-1.401^{* * *} \\
(0.187)\end{array}$ & $\begin{array}{l}-0.905 \\
(0.136)\end{array}$ & $\begin{array}{c}-0.901^{* * *} \\
(0.131)\end{array}$ & $\begin{array}{c}-0.942^{* * *} \\
(0.181)\end{array}$ & $\begin{array}{c}-1.756^{* * *} \\
(0.358)\end{array}$ \\
\hline $\mathrm{C}$ & $\begin{array}{c}1.441^{* * *} \\
(0.187)\end{array}$ & $\begin{array}{c}1.411^{* * *} \\
(0.156)\end{array}$ & $\begin{array}{c}2.544^{* * *} \\
(0.732)\end{array}$ & $\begin{array}{c}0.788^{* * *} \\
(0.166)\end{array}$ & $\begin{array}{c}0.312 \\
(0.446)\end{array}$ & $\begin{array}{c}9.573^{* * *} \\
(2.700)\end{array}$ \\
\hline $\begin{array}{l}\text { Obs with Dep }=1 \\
\text { Total obs }\end{array}$ & $\begin{array}{l}271 \\
381\end{array}$ & $\begin{array}{l}255 \\
360\end{array}$ & $\begin{array}{l}335 \\
462\end{array}$ & $\begin{array}{l}335 \\
462\end{array}$ & $\begin{array}{l}233 \\
320\end{array}$ & $\begin{array}{l}199 \\
284\end{array}$ \\
\hline McFadden R-squared & 0.112 & 0.159 & 0.089 & 0.084 & 0.133 & 0.284 \\
\hline LR statistic & 51.437 & 69.183 & 48.394 & 45.730 & 49.770 & 98.313 \\
\hline Prob (LR statistic) & $(0.000)$ & $(0.000)$ & $(0.000)$ & $(0.000$ & $(0.000)$ & $(0.000)$ \\
\hline
\end{tabular}


Symmetry and Convergence in Monetary Unions

\section{Appendix 8. Beta convergence estimates}

The results in the Table below regress the change in NORD index on the usual sets of control used in Table 1 plus the value of NORD in the first period, i.e. $\operatorname{NORD}(0)$. The results show that there is no convergence across the panel when a test for $\beta$-convergence is used.

\begin{tabular}{|c|c|c|c|c|c|c|}
\hline & \multicolumn{6}{|c|}{$1991-2015$} \\
\hline \multirow[b]{2}{*}{ NORD $(0)$} & Fiscal & Financial & External & Trade & Labour & All \\
\hline & $\begin{array}{r}0.003534 \\
(0.027)\end{array}$ & $\begin{array}{c}0.002187 \\
(0.032)\end{array}$ & $\begin{array}{c}0.010137 \\
(0.026)\end{array}$ & $\begin{array}{c}0.003679 \\
(0.026)\end{array}$ & $\begin{array}{r}0.003471 \\
(0.032)\end{array}$ & $\begin{array}{c}-0.00102 \\
(0.043)\end{array}$ \\
\hline Debt/GDP & $\begin{array}{r}-0.002 \\
(0.019)\end{array}$ & & & & & $\begin{array}{c}0.035 \\
(0.032)\end{array}$ \\
\hline Adj. Budget Balance & $\begin{array}{r}-0.174 \\
(0.166)\end{array}$ & & & & & $\begin{array}{c}-0.251 \\
(0.250)\end{array}$ \\
\hline Corporate bond spread & & $\begin{array}{c}0.089 \\
(0.295)\end{array}$ & & & & $\begin{array}{c}0.129 \\
(0.374)\end{array}$ \\
\hline Gvt bond spread & & $\begin{array}{c}0.278 \\
(0.500)\end{array}$ & & & & $\begin{array}{c}0.370 \\
(0.654)\end{array}$ \\
\hline $\begin{array}{l}\text { 3-month interbank } \\
\text { spread }\end{array}$ & & $\begin{array}{c}0.540 \\
(0.640)\end{array}$ & & & & $\begin{array}{c}1.290 \\
(0.915)\end{array}$ \\
\hline $\begin{array}{l}\text { Avg on consumer loans } \\
\text { spread }\end{array}$ & & $\begin{array}{l}-0.204 \\
(0.148)\end{array}$ & & & & $\begin{array}{c}-0.660^{* *} \\
(0.276)\end{array}$ \\
\hline Return on equity diff. & & $\begin{array}{c}0.000 \\
(0.003)\end{array}$ & & & & $\begin{array}{c}0.089 \\
(0.054)\end{array}$ \\
\hline FDI & & & $\begin{array}{c}-0.110^{* * *} \\
(0.041)\end{array}$ & & & $\begin{array}{c}-0.131^{* *} \\
(0.056)\end{array}$ \\
\hline Reer (CPI adj.) & & & $\begin{array}{c}0.015 \\
(0.052)\end{array}$ & & & $\begin{array}{l}-0.078 \\
(0.102)\end{array}$ \\
\hline Trade openness (\%GDP) & & & & $\begin{array}{r}-0.008 \\
(0.013)\end{array}$ & & $\begin{array}{l}-0.003 \\
(0.024)\end{array}$ \\
\hline EPL temporary & & & & & 0.101 & -1.387 \\
\hline PMR & & & & & -0.732 & 1.298 \\
\hline & & & & & $(1.606)$ & $(2.205)$ \\
\hline EZ membership & -1.268 & -1.213 & -0.951 & -1.508 & -1.575 & 0.340 \\
\hline 1999 & $(1.016)$ & (1.139) & $(0.919)$ & $(0.916)$ & (1.174) & $(1.542)$ \\
\hline $\mathrm{C}$ & -0.819 & -0.821 & -1.859 & 0.423 & 0.830 & 4.663 \\
\hline & $(2.419)$ & $(2.433)$ & $(6.171)$ & $(1.899)$ & $(2.884)$ & $(11.897)$ \\
\hline Adj-R2 & -0.002 & -0.006 & 0.016 & 0.002 & -0.007 & 0.027 \\
\hline Durbin-Watson & 2.249 & 2.326 & 2.377 & 2.343 & 2.215 & 2.358 \\
\hline J-Stat (p-value) & $(0.531)$ & $(0.663)$ & $(0.030)$ & $(0.280)$ & $(0.765)$ & $(0.103)$ \\
\hline
\end{tabular}


Nauro F. Campos and Corrado Macchiarelli

\section{Appendix 9. Phillips-Sul results}

\begin{tabular}{|c|c|c|c|c|c|c|c|c|c|c|}
\hline & \multicolumn{4}{|c|}{ Original clubs' $\log (\mathrm{t})$ tests } & \multicolumn{4}{c|}{$\log (\mathrm{t})$ test for club merging } \\
\hline $\log (\mathrm{t})$ & Club1 & Club2 & Club3 & Club4 & Club5 & $\log (\mathrm{t})$ & Club1+2 & Club2+3 & Club3+4 & Club4+5 \\
\hline Coeff & 0.853 & -0.585 & 0.465 & 1.433 & -0.817 & Coeff & -0.891 & -1.3 & -0.398 & -1.538 \\
\hline T-stat & 0.601 & -0.83 & 0.283 & 0.798 & -1.179 & T-stat & -1.378 & -1.478 & -0.395 & -2.895 \\
\hline
\end{tabular}




\section{Recent LEQS papers}

Costa Font, Joan \& Perdikis, Laurie “Varieties of Health Care Devolution: "Systems or Federacies"?" LEQS Paper No. 130, February 2018

Calrsson, Ulrika “The Perennial Thirty Years' War” LEQS Paper No. 129, February 2018

Isiksel, Turkuler “Square peg, round hole: Why the EU can't fix identity politics” LEQS Paper No. 128, January 2018

Hancké, Robert \& Vlandas, Tim “The Politics of Disinflation” LEQS Paper No. 127, December 2017

White, Jonathan “Between Rules and Discretion: Thoughts on Ordo-liberalism" LEQS Paper No. 126, November 2017

Costa Font, Joan \& Zigante, Valentina “Building 'Implicit Partnerships'? Financial Long Term Care Entitlements in Europe" LEQS Paper No. 125, October 2017

Bohle, Dorothee “Mortgaging Europe's periphery” LEQS Paper No. 124, September 2017

Iordanoglou, Chrysafis \& Matsaganis, Manos “Why Grexit cannot save Greece (but staying in the Euro area might)" LEQS Paper No. 123, August 2017

Saka, Orkun “'Domestic banks as lightning rods? Home bias during the Eurozone crisis” LEQS Paper No. 122, February 2017

Coulter, Steve “Signalling Moderation: UK Trade Unions, 'New Labour' and the Single Currency" LEQS Paper No. 121, December 2016

Di Cataldo, Marco "Gaining and losing EU Objective 1 funds: Regional development in Britain and the prospect of Brexit" LEQS Paper No. 120, November 2016

Avlijas, Sonja "Vicious and virtuous cycles of female labour force participation in post-socialist Eastern Europe" LEQS Paper No. 119, November 2016

Crescenzi, Riccardo \& Iammarino, Simona. “Global Investments and Regional Development Trajectories: the Missing Links" LEQS Paper No. 118, October 2016

Teasdale, Anthony. “The Fouchet Plan: De Gaulle's Intergovernmental Design for Europe” LEQS Paper No. 117, October 2016

Campos, Nauro F. \& Macchiarelli, Corrado. "Core and Periphery in the European Monetary Union: Bayoumi and Eichengreen 25 Years Later" LEQS Paper No. 116, September 2016

Foresti, Pasquale \& Napolitano, Oreste. “On the Stock Markets' Reactions to Taxation and Public Expenditure" LEQS Paper No. 115, September 2016

Gelepithis, Margarita. "Rethinking the paradox of redistribution: how private insurance and means testing can lead to universalizing reform" LEQS Paper No. 114, July 2016

Costa-Font, Joan \& Turati, Gilberto. “Regional Health Care Decentralization in Unitary States: Equal Spending, Equal Satisfaction?" LEQS Paper No. 113, June 2016

Bilgel, Firat \& Can Karahasan, Burhan. “Thirty Years of Conflict and Economic Growth in Turkey: A Synthetic Control Approach" LEQS Paper No. 112, June 2016 


\section{LEQS}

European Institute

London School of Economics

Houghton Street

WC2A 2AE London

Email: euroinst.LEQS@1se.ac.uk

http://www2.lse.ac.uk/europeanInstitute/LEQS/Hom

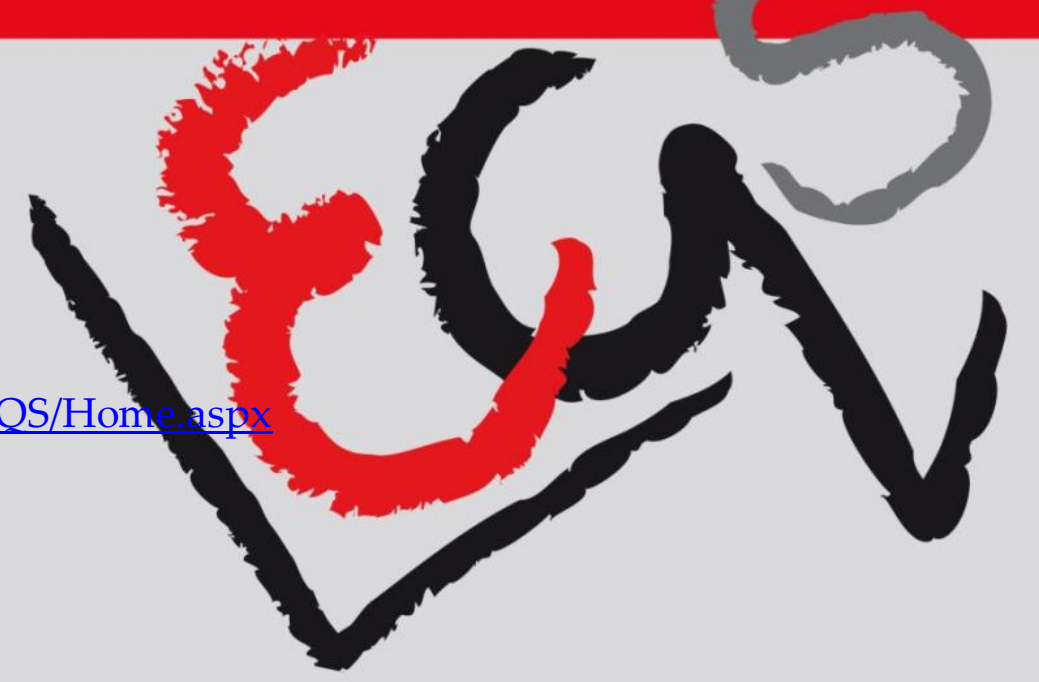

